\title{
Study of connectivity of open framework gravel facies in the Canterbury Plains aquifer using smoke as a tracer
}

DOI:

10.1144/SP440.10

\section{Document Version}

Accepted author manuscript

Link to publication record in Manchester Research Explorer

\section{Citation for published version (APA):}

Burbery, L. F., Moore, C. R., Jones, M., Abraham, P. M., Humphries, B. L., \& Close, M. E. (2017). Study of connectivity of open framework gravel facies in the Canterbury Plains aquifer using smoke as a tracer. Geological Society, London, Special Publications, 440. https://doi.org/10.1144/SP440.10

\section{Published in:}

Geological Society, London, Special Publications

\section{Citing this paper}

Please note that where the full-text provided on Manchester Research Explorer is the Author Accepted Manuscript or Proof version this may differ from the final Published version. If citing, it is advised that you check and use the publisher's definitive version.

\section{General rights}

Copyright and moral rights for the publications made accessible in the Research Explorer are retained by the authors and/or other copyright owners and it is a condition of accessing publications that users recognise and abide by the legal requirements associated with these rights.

\section{Takedown policy}

If you believe that this document breaches copyright please refer to the University of Manchester's Takedown Procedures [http://man.ac.uk/04Y6Bo] or contact uml.scholarlycommunications@manchester.ac.uk providing relevant details, so we can investigate your claim.

\section{OPEN ACCESS}




\section{STUDY OF CONNECTIVITY OF OPEN FRAMEWORK GRAVEL FACIES IN THE CANTERBURY PLAINS AQUIFER USING SMOKE AS A TRACER}

4 Lee F. Burbery ${ }^{1 \star}$, Catherine R. Moore ${ }^{1 \dagger}$, Merren A. Jones ${ }^{2}$, Phillip M. Abraham ${ }^{1}$, Bronwyn Humphries ${ }^{1}$, 5 Murray E. Close ${ }^{1}$

6

7 Abstract

8 Open framework gravels (OFGs) are an inherent textural component of alluvial gravel outwash deposited 9 by braided river systems. Being exceptionally permeable, they play a significant role in facilitating 10 transmission of water and contaminants through alluvial gravel aquifers. Understanding how connected

11 OFG facies are is helpful for making informed predictions about groundwater flow and contaminant 12 transport through such aquifer systems. In this work, an examination was made of a section of the Rakaia 13 fan, Canterbury, New Zealand. A 3x3 grid of large diameter auger holes were drilled in close proximity to a 14 sea cliff, which provided very good 3D exposure of the fan architecture. A novel smoke tracing experiment and water tracing field tests were conducted to measure the dynamic connectivity of OFG facies. Smoke proved to be an effective tracer for measuring the inter-connectedness of OFG over set distances of $5 \mathrm{~m}$. The water tracing tests confirmed OFG are connected across much longer distances - in excess of $18 \mathrm{~m}$. Results from both tests revealed how rapid, and non-uniform, aqueous transport can be through alluvial outwash materials. The connectivity information will be used to improve realisations of heterogeneity of the Canterbury Plains aquifer and inform hydrogeological modelling in the future.

Keywords: Rakaia fan, New Zealand; smoke tracer test; open framework gravel; connectivity. 
Open framework gravels (OFGs) - also known as openwork gravels - are an inherent component of the alluvial architecture of gravel-bed braided river deposits. They are characterised by a unimodal grain-size distribution with negligible sand content, a mean grain size greater than $2 \mathrm{~mm}$ and sorting coefficients less than 2.5 phi (Regli et al., 2002; Lunt et al., 2004). Within gravelly fluvial deposits, OFG are either planarstratified or cross-stratified, commonly forming units centimetres to decimetres thick and metres to tens of metres in lateral extent (Smith, 1974; Steel \& Thompson, 1983; Browne \& Naish, 2003; Lunt et al., 2004). A number of sorting mechanisms have been proposed for the origin of OFG in gravel-bed river deposits, including the winnowing or infiltration of sand matrix associated with periodic, temporal fluctuations in the flow strength (Clifton, 1973; Smith, 1974; Ikeda, 1982; Steel \& Thompson, 1983), the migration of smaller bedforms (such as bedload sheets) over dune crests (Rust, 1984; Anketell \& Rust, 1990; Carling, 1996), or flow separation at the crests of large dunes and bars, coupled with size segregation during avalanching on the bedform leeside (Carling \& Glaister, 1987; Anketell \& Rust, 1990; Lunt \& Bridge, 2007). As a result of the absence of a sand matrix, OFG exhibit exceptionally high permeabilities (Cary, 1951; Jussel et al., 1994; Klingbeil et al.,1999; Lunt et al, 2004; Dann et al., 2009; Ferreira et al., 2010) and, as a consequence, they play an important role in the rapid transmission of water and contaminants through alluvial gravel deposits that, in many parts of the world, form important aquifers (Zekster \& Everett, 2004; Dann et al., 2008; Margat \& van der Gun, 2013). Being macroporous, they are poor at filtering microbes (Close et al., 2006) and are implicated in the very low microbial removal rates that characterise alluvial gravel aquifer systems (Sinton, 1980; Rossi et al., 1994; Pang, 2009; Flynn et al., 2015). The complex arrangement of OFG in river deposits is also believed to promote non-equilibrium dispersion and complex plume migration that has been observed in groundwater tracing studies (e.g. Pang \& Close, 1999; Close et al., 2004). Obtaining hard data to evaluate the 3D interconnectedness of OFG within the alluvial architecture of braided river deposits remains a challenge, due the general complication of accessing the subsurface environment and making direct observations on undisturbed sediments at high spatial resolutions.

Descriptive methods, whereby site-specific geological or geophysical data are mapped and translated into 3D hydrofacies models (Koltermann \& Gorelick, 1996), provide a useful approach to making quantitative study of hydrogeological systems formed from alluvial deposits (Huggenberger \& Regli, 2006; Gershenzon et al., 2015). Due to the impracticality of making visual observation of saturated sediments, field datasets for such studies tend to be obtained from the unsaturated zone (e.g. Klingbeil et al., 1999; Anderson et al., 1999; Lunt et al., 2004; Weissmann et al., 2015). Conventional practice is to prepare a lithofacies map from field observations made in bores and trenches and/or on cliff exposures. Ground penetrating radar or wireline logging methods are sometimes employed as techniques to map the physical space between points of direct observation. Porosity measurement on core samples and hydraulic conductivity measures, be it from disturbed or undisturbed samples, using air permeametry or traditional water permeametry methods, or simply inferred from grain size distributions, tend to be the limit of practical hydraulic assessment. Lunt et al.'s (2004) examination of the Sagavanirktok River in Alaska 
measures only of the spatial distribution of parameters that govern groundwater flow and mass transport, which Renard \& Allard (2013) describe as a form of static connectivity measurement. To the best of our knowledge, no outcrop studies made on alluvial deposits have ever reported of direct in situ measurements of the connectivity of the main hydrofacies, which Renard \& Allard (2013) refer to as a measure of dynamic connectivity.

Although smoke has been used as a tracer in land drainage studies for detecting soil macropores (e.g. Fleming \& Bradshaw, 1992; Fox et al., 2012), and in examining the connectivity of fractures in karst terrain (e.g. Taucer, 2005; Milanović, 2010), we are not aware of smoke tracer experiments ever having been applied in the study of gravelly fluvial deposits. In this paper we present the results of a 3D field study of OFG within the late Quaternary, braided river deposits that form part of the Canterbury Plains, New Zealand (NZ). The aim of the study was to evaluate the 3D interconnectedness of OFG within the alluvial architecture of the braided river deposits. A key objective was to test the usefulness of smoke applied as a tracer for this purpose and as a way of obtaining hard information on dynamic connectivity that might be used in future groundwater modelling work. Water was also used as a tracing element in the field study and we discuss the limitations of the two different tracing methods. The work is part of our ongoing research, aimed at developing improved predictive models for groundwater resource management. The implications of the findings for resource management of alluvial gravel aquifers is discussed.

\section{Geological setting: Kyle, on the Canterbury Plains}

The Canterbury Plains on the South Island, NZ formed by coalescence of several alluvial fans sourced from the Southern Alps (Leckie, 1994; 2003; Bal, 1996; Ashworth et al., 1999; Browne \& Naish, 2003). At up to $70 \mathrm{~km}$ wide and $185 \mathrm{~km}$ long, the plains cover approximately $8,000 \mathrm{~km}^{2}$ and their eastern margin is demarcated by the Pacific Ocean. The alluvial gravels that form them host NZ's largest and most valuable groundwater resource that is heavily utilised for irrigation, industrial and potable water supply (Bal, 1996; Brown, 2001). Our field-study was made at the sea-cliff exposures, at Kyle [43.9433S, 172.0678E], located $12 \mathrm{~km}$ south of the Rakaia River mouth (Figure 1), and approximately $50 \mathrm{~km}$ from the range front of the Southern Alps. The coastline at Kyle is retrograding at a rate of approximately one metre per year (Gibb, 1978), and is incised with gullies (dongas), which provide a third dimensional aspect to the exposed sediments. During the Last Glacial Maximum, when sea-levels fell by $120 \mathrm{~m}$ (Newnham et. al., 1999) and the coastline moved offshore by approximately $60 \mathrm{~km}$ from its present location (Rowan et al., 2012), the Kyle site would have been at a mid-point on the Rakaia fan (Browne \& Naish, 2003, Fig.5).

The $13 \mathrm{~m}$ thick cliff section at Kyle consists of a vertically-stacked series of gravel packages, each package representing one or two channel flow depths in height (as determined from channel fills and barforms (see Figure 2)) and possessing internally variable textural and structural attributes that result in a wide range of hydraulic conductivities. Separating these packages are sub-horizontal surfaces with variable degrees of lateral extension. These range in order from 'within channel' surfaces that extend up to a few 10 s of metres and are associated with the migration of bar forms, to major erosion surfaces that 
extend over 100s of metres and appear to represent periods of little to no deposition across the channel belt. The whole gravel sequence is overlain by a 0.3-0.4 $\mathrm{m}$ thick blanket of loess and modern soil. Mean palaeoflow direction is perpendicular to the cliff face. Optically stimulated luminescence dating of interbedded sand bodies occurring at $1.4 \mathrm{~m}$ and $11 \mathrm{~m}$ below the cliff top, suggests that the gravel stratigraphy was deposited approximately between $21.5 \pm 1.3 \mathrm{ka}$ and $31.1 \pm 1.6 \mathrm{ka}$ bp (Rowan et al., 2012), i.e. during the last glacial period (Ashworth et al., 1999; Leckie, 2003; Browne \& Naish, 2003). The loess sheet was deposited during the postglacial from $\approx 13$ ka (Tonkin, 1974; Berger et al., 1996).

\section{$87 \quad$ Research Methods}

\section{$88 \quad$ Field investigation}

\section{Mapping the braided alluvial architecture}

A $25 \mathrm{~m}$-wide cliff section, and a face in an adjacent donga where the top $6 \mathrm{~m}$ of alluvial deposits were exposed, were photographed using a digital camera. Mean palaeoflow direction is perpendicular and parallel to the cliff and donga faces, respectively. In order to maintain a constant scale and minimise distortion, the photographs were taken from a fixed distance from the cliff, at $10 \mathrm{~m}$ intervals with $50 \%$ overlap. The overlapping photographs were joined to make a photomontage. Detailed logging of the cliff and donga exposures was undertaken and key lithological units, internal sedimentary structures, and erosion surfaces were mapped onto the resulting 2D photo panels (Figure 2). To complement the exposed cliff faces and facilitate tracing tests, nine boreholes (coded K1:K9) were drilled, $18 \mathrm{~m}$ inland from the cliff face (in the up flow direction), each to a depth of $6.0 \mathrm{~m}$, using a $1.2 \mathrm{~m}$ diameter bucket auger. The holes were spaced $5 \mathrm{~m}$ apart on a $3 \times 3$ Cartesian grid, the $\mathrm{x}$-axis of which was oriented at $151^{\circ}$, i.e. aligned with the mean palaeoflow direction and in-line with three vertical transects $(\mathrm{C} 1: \mathrm{C} 3)$ surveyed on the sea cliff (see Figure 2 inset). A vadose zone sampling rig (Close et al., 2011) was used to enable safe down-hole access. Photomosaics of sediments exposed in the open bores were compiled from images collected using a camera mounted on a rigid pole that was manually lowered down the holes, employing a fixed tape measure as a depth reference marker. Detailed logging of the four corner bores (K1, K3, K7, K9) were completed in situ and recorded on the photomosaics, while the lithological and structural characteristics of the remaining five holes were interpreted from photographic evidence only. The site was surveyed using GPS real time kinematic methods, referenced to established benchmarks from the Land Information NZ Geodetic Database, to aid correlating between the boreholes, donga and cliff face.

Examples of cases where hydrofacies maps have been produced for braided river deposits, like those at Kyle, include Klingbeil et al. (1999), Heinz \& Aigner (2003), Lunt et al. (2004) and Bayer et al. (2011). Klingbeil et al. (1999) distinguished 23 lithofacies, condensing these to five hydrofacies, whereas Lunt et al. (2004) assumed four separate textural classes in developing a hydrogeological model, these being: sand, sandy gravel, gravelly sand and open framework gravel. In contrast, Heinz \& Aigner (2003), and Bayer et al. (2011) expanded the number of lithofacies they categorised into more numerous hydrofacies (12 from 5, and 10 from 4, respectively). In this field-study, we focussed on mapping four separate textural 
classes, three of which (sand (S); sandy gravel (SG), and OFG) we adopted from a previous study Dann et al. (2009) made of the hydrogeological properties of Rakaia fan sediments. The fourth textural class we assumed was clay-bound gravel (CBG). Reference images of the four representative facies are provided in Figure 3.

The existence of CBG in gravelly alluvial deposits was first reported by Cary (1949). Braden (1955) and Browne (2002) have since suggested it represents a post-depositional sedimentary unit, resulting from either interstitial or ground water movement through what was originally an OFG deposit. In our mapping we identified CBG as being clast-supported gravel whose pore structure was heavily coated (and to the visual eye, completely plugged) with mud (see Figure 3d for an example). Heinz et al. (2003) reported a similar textural class in their hydrofacies analysis of alluvial outwash in the Rhine glacier region, Germany. They defined it as massive clast-supported gravel with subordinate fines of mainly silt, and determined its hydraulic conductivity to be $1.6 \times 10^{-6} \pm 1.1 \times 10^{-6} \mathrm{~m} / \mathrm{s}$, or about four orders-of-magnitude smaller than that of OFG and about two-orders of magnitude smaller than hydrofacies containing sand. We use these published hydraulic property values as justification for our underlying assumption of CBG being a discrete

Accurate identification of the textural characteristics of the deposits in the cliff, donga and borehole cut faces required removal of the surface sediments. The distribution of the four textural classes within the mapped architecture was established by abseiling down the cliff face and scraping off the surface sediments along three vertical transects (C1:C3), spaced $5 \mathrm{~m}$ apart. The same was done for three similar vertical transects (D1:D3) on the donga face (Figure 2 inset). Disturbed samples of representative samples of each class were collected from the boreholes and subjected to particle size distribution (PSD) analysis. Due to technical problems obtaining a clean representative bulk sample of CBG, no actual physical samples of this facies were collected for PSD analysis. OFG exhibiting a heavy clay-coating, indicative of a changing state progressing towards clay-bound, were however sampled.

\section{Smoke and water tracer experiments}

Smoke tracer tests were performed in the open bores. A glycerine liquid-based smoke/fog machine (commercially available as a party smoke machine) was suspended midway down the test bore, the top of which was temporarily sealed with a large wooden cover complete with viewing window. A leaf blower machine attached to the cover was used to exert a small positive pressure into the capped test bore that was measured with a downhole pressure sensor. The smoke machine was turned on in the test bore by remote control and the time and depth at which smoke began to appear in the neighbouring bores was recorded. Smoke tracing tests were conducted from centrally-located bores $\mathrm{K} 2, \mathrm{~K} 5$ and $\mathrm{K} 8$, with a repeat test made from K5. Each test was run for approximately 75 minutes, which was the time taken for the 
$187 \quad v_{i j}=\left(\frac{L}{t}\right)_{i j}$

where subscripts $i$ and $j$ are indices that denote measurement between a test bore $i$ and observation bore $j$.

Following the smoke tracer tests that examined connectivity across the extent of the bore-spacings, two qualitative tests were conducted using water to determine connectivity of OFG facies observed in the bores and in the cliff and donga exposures. Drill cuttings topped with a $1 \mathrm{~m}$ seal of bentonite clay were used to back-fill bores $\mathrm{K} 3$ and $\mathrm{K} 9$ to the base level of the shallowest recorded OFG that occurred at roughly $3.0 \mathrm{~m}$ below ground level $(\mathrm{bgl})$. In two separate tests, water was then injected into the said bores through a $100 \mathrm{~mm}$ diameter irrigation hose, at a flow rate of approximately $25 \mathrm{~L} / \mathrm{s}$. Observations were made of where and when the water emerged on the exposed faces.

\section{Data analysis}

\section{Transition probability geostatistical modelling}

Transition probability geostatistics models (TPROGS) (Carle \& Fogg, 1996; Carle et al. 1998) describe the juxtapositional tendencies of strata and provide a mathematical basis for exploring equally probable realisations of strata and their spatial variability. These models and the realisations based on them are used in Monte Carlo analyses when exploring the stochastic range of outputs that may be plausible in predictive groundwater modelling problems (e.g. Hansen et al. 2014; Maghrebi et al., 2015). Use of these geostatistical methods have the advantage of honouring borehole data unlike sediment depositional model alternatives. In this work, we evaluated the transition probabilities between the four textural classes mapped at Kyle. We did this primarily as a means of mathematically cataloguing the data in expectation that we will use it in generating stochastic realisations of the alluvial deposits at Kyle in a future accompaniment to this paper. For the vertical (z-) direction, the matrix of transition probabilities was prepared from observational data obtained from the textural mapping down the vertical transects $\mathrm{K} 1: \mathrm{K} 9$, $\mathrm{C1}$ :C3 and D1:D3. In the case of horizontal directions, i.e. along the mean palaeoflow direction ( $x-$ direction) and transverse to this (y-direction), embedded probabilities were used and derived from the vertical transition probabilities and Walther's Law (Elfeki \& Dekking, 2005).

\section{Connectivity measures and inferred anisotropy}

Connectivity of individual OFG facies was determined directly from the measured smoke arrival times and locations of discrete OFG strata from which smoke was emitted in the observation bores. The measured pressure differential for each smoke tracer test was small (average $0.45 \mathrm{mbar}$ ) and did not differ significantly between individual tests $(p<0.01)$, which precluded the need to make any corrections to observed travel time datasets. Individual arrival times $t$ were directly translated to effective velocities $v$, considering the horizontal distance $L$ separating test and observation bores: 
Although a very simplified interpretation of the smoke tracer data, we also made a more generalised inference of the anisotropy of the Canterbury Plains aquifer sediments, determined from the calculated velocities. For this we assumed the velocity at which smoke travels through OFG is a proxy for the effective hydraulic conductivity of the OFG, and imagined the system as a lumped hydrogeological model parameterised with a uniform hydraulic conductivity value. The relative horizontal hydraulic conductivity $K^{*}$ in all observed directions was calculated for each test bore, using the mathematical relationship:

$$
K_{i j}^{*}=v_{i j} / v_{\max }
$$

where the subscript max denotes the maximum velocity determined from all observations (from all tests). A crude estimate of the horizontal anisotropy ratio $\alpha$ of the bulk sedimentary system was then obtained from comparing $K_{i j}^{*}$ values related to well pairs aligned parallel with the principle direction of sediment deposition against those aligned perpendicular to this, defined as:

$202 \quad \alpha=\frac{\bar{K}_{x x}^{*}}{\bar{K}_{y y}^{*}}$

where $x$ and $y$ follow the spatial coordinate system marked in Figure 2, and $\bar{K}^{*}$ symbolises the averaged relative hydraulic conductivity values.

\section{Results}

\section{Distribution of the textural classes within the braided alluvial 208 architecture}

209 Figure 2 shows the distribution of the four textural classes within the alluvial architecture, as preserved in the cliff, donga and borehole sections. Figure 3 includes PSD curves determined for representative facies, from which the unimodal, well sorted characteristics of OFG are evident. Transiograms for the four textural classes, together with the best-fit Markov chain model, are plotted in Figure 5. The volumetric proportions of the textural classes in the deposit at Kyle can be inferred from the sills of the transiograms. According to the statistics calculated for sediments logged on the vertical transects (K1:K9, C1:C3, D1:D3), SG makes up approximately $67 \%$ of the lithology at Kyle (by volume), compared to $18 \%$ for OFG, $11 \%$ for CBG and just $4 \%$ for $S$.

Laterally extensive ( $>25 \mathrm{~m}$ ), units of medium- to large-scale (between 0.4 and $1 \mathrm{~m}$ thick) inclined strata is the most common component of the deposits in the cliff face (Figure 2). The basal erosion surfaces are planar to arcuate, with basal lags of coarse cobble sized clasts. Within each unit, the cross-strata are composed of alternating packages of SG and OFG, and minor wedge-shaped sand drapes. OFG foresets are predominantly planar in geometry and the inclination of the cross-strata varies in dip between $6^{\circ}$ and $26^{\circ}$. Individual packages of OFG cross-strata vary from $0.2 \mathrm{~m}$ thick and $0.25 \mathrm{~m}$ in lateral extent for low angle sets, to $1 \mathrm{~m}$ thick and $3.5 \mathrm{~m}$ in lateral extent for high angle sets. OFG foresets are very well sorted, with gravel-sized clasts often fining upwards. Vertically, cross-strata of OFG occur in stacked sets, with 
successive sets occasionally containing foresets with the opposite sense of dip. More commonly, open framework cross-strata are bound above and below by SG.

OFG also occurs in laterally extensive (4-5 $\mathrm{m}$ across flow and $>15 \mathrm{~m}$ in the down flow direction), planar bedded units up to $0.3 \mathrm{~m}$ thick. These units are commonly underlain and/or overlain by planar bedded units of SG. Perpendicular to the palaeoflow direction the planar bedded units lack internal structure, but parallel to the flow direction (in the donga section) they are locally well imbricated or fine upward. The pattern of OFG interbedded by SG is reflected in the vertical juxtapositional tendencies summarised in the z-direction, where transitional probabilities evaluated for OFG and SG (Figure 5c) indicate that at an average separation distance of around $0.2 \mathrm{~m}$ OFG will transition to SG.

Within the top $2.5 \mathrm{~m}$ of the section, both cross-stratified and planar bedded units are overlain by thin, discontinuous, horizontal to low angle, sheets of sand (Figure 2; Figure 3a). OFG are entirely absent within this top section at Kyle, including the cliff, donga and bore hole sections. The sand sheets are up to $0.2 \mathrm{~m}$ thick and $5 \mathrm{~m}$ in width. They are internally massive to laminated, and occur parallel to and underly the major erosive surfaces. Laterally they grade into cross-bedded sands.

The distribution of CBG within the section is closely associated with the distribution of OFG (Figure 2). This aspect is mirrored in the similar transitional probabilities calculated for these textural classes (Figure 5c). From below $4.5 \mathrm{~m}$, clast-supported gravel within the bores was rarely observed to be 'open', instead pore interstices were increasingly plugged with mud, and mapped as CBG. In particular, bores K8 and K9 positioned in the north-east of the array were observed to contain much CBG. CBG also dominated the sediment profile below $4 \mathrm{~m}$ on the donga face, at the opposite southern end of the field-site. The CBG at the donga correlated with a $0.5 \mathrm{~m}$ thick bed of CBG exposed on the south end of the sea cliff (Figure 2). CBG also forms thin units ( $<10 \mathrm{~cm}$ thick) along the bounding (erosion) surfaces, in zones of contrasting permeabilities, such as at the interface between units of OFG and sandy gravel. Evidence of CBG formation concentrating at the base of OFG units can be seen in Figure 3c.

Deposition of both planar and cross-stratified units of SG and OFG are associated with the downstream migration of bars (Siegenthaler \& Huggenberger, 1993; Lunt et al., 2004). The medium- to large-scale cross-strata are interpreted as slip faces (high angle) or accretion surfaces (low angle) associated with bar margins, and similar to Facies B \& H of Ashworth et al. (1999) and Facies Gp of Browne \& Naish (2003) in previous studies of the Canterbury Plains. Planar bedded units of OFG or SG are identified as 'bar core' deposits, attributed to the migration of bedload sheets (Ramos \& Sopeña, 1983; Lunt et al., 2004), and correspond to Facies G of Ashworth et al. (1999) and Facies Gm of Browne \& Naish (2003). The sand sheets are interpreted as resulting from deposition on the bar top or low angle bar margins, and correspond to Facies A of Ashworth et al. (1999). The bar margins and bar cores grade laterally into each other, and into channel fills occasionally containing arcuate plugs of sand. 


\section{Smoke}

267 The results of the smoke tracer experiment confirmed that OFGs are truly 'open' since smoke readily 268 transported between bores along this facies. Connectivity was not uniform in all directions, reflecting both 269 the heterogeneity and anisotropy of the alluvial sediments. Figure 6 maps the connectivity between OFG 270 facies, as inferred from smoke tracer tests conducted from bores $\mathrm{K} 2, \mathrm{~K} 5$ and $\mathrm{K} 8$. It is helpful to note that smoke was never detected beyond the most neighbourly bore and there was no evidence of smoke emission from either the donga face or exposed cliff face that were more than $15 \mathrm{~m}$ distant from any test

The fastest travel time we recorded was 48 seconds for smoke travelling between K2 and K1 via what we interpreted to be a co-set of planar strata. The latest observed smoke arrival was 30 minutes, between $\mathrm{K} 5$ and $\mathrm{K} 1$, although in some cases no apparent smoke was detected to have travelled between adjacent bores, suggestive of no apparent connectivity between OFG. Examples where no smoke was transmitted between test-observation bore pairs were: $\mathrm{K} 5-\mathrm{K} 8, \mathrm{~K} 5-\mathrm{K} 9$ and $\mathrm{K} 2-\mathrm{K} 4$. Fastest velocities in all cases corresponded to the mean palaeoflow direction, i.e. NNW-SSE - a result that is marked also by the average bulk horizontal anisotropy ratio value of $\alpha=6$ that we calculated for the alluvial sedimentary system. Smoke tracing results proved commensurate, in the sense that the relative permeability inferred between a test and observation bore was identical to that inferable when the bores' roles were reversed.

We identified that smoke was transmitted via both planar strata, as well as cross-stratified OFG. The thickness of the individual OFG beds through which smoke travelled rapidly ranged from $50 \mathrm{~mm}$ to $0.29 \mathrm{~m}$, although in bores $\mathrm{K} 4, \mathrm{~K} 5$ and $\mathrm{K} 2$ these beds were part of packaged sets of OFG forming a layer of between $0.7 \mathrm{~m}$ and $1 \mathrm{~m}$ thickness. In the case of the test from bore $\mathrm{K} 5$, smoke was observed to travel relatively slowly via the lower layer of OFG, at $4 \mathrm{~m}$ depth, connecting to $\mathrm{K} 2$ and $\mathrm{K} 3$. A similar weak connection offered through the deeper layer of OFG was detected in the test conducted from K8 from which smoke travelled to bores $\mathrm{K} 6$ and $\mathrm{K} 9$, as can be seen in Figure 6. Overall, the greatest connectivity appeared to be offered through shallower OFG beds, although we cannot dismiss the possibility that this observation was biased by the depth at which the smoke machine was suspended down the test holes.

A distinct result of the smoke tracer tests was the lack of any observable hydraulic connection between OFG in test bore $\mathrm{K} 5$ and OFG facies mapped in both $\mathrm{K} 8$ and $\mathrm{K} 9$, to the north (Figure 6). Whereas a $0.7 \mathrm{~m}$ thick layer of OFG comprised of three sets of planar OFG strata was logged at $3 \mathrm{~m}$ depth in $\mathrm{K} 5$ and many other bores, the same strata were notably missing in both K8 and K9. In those bores, OFG at the equivalent depth displayed what we interpreted to be cross-stratification, indicating a separate bed-form and $\mathrm{K} 9$ displayed a reasonably strong hydraulic connection, which extended across to $\mathrm{K} 7$, positioned upgradient. 
Water poured in to each of bores K3 and K9 drained via OFG facies as rapidly as it was added; the measured static water level in both cases being $2.9 \mathrm{~m} \mathrm{bgl}$, over the period of the tracing test. Although both bores represented those positioned down-gradient on the bore array, results indicated water draining through the sediments under gravity flowed topographically up-gradient, seeping from OFG facies exposed at depth in adjacent bores and beyond. Again, measured lag times to onset of observed water seepage, indicated preferential flow in a NNW-SSE direction, corresponding with the mean palaeoflow direction.

Unlike the smoke tracing tests, water tracing tests confirmed some larger-scale hydraulic connectivity between OFG facies in the bores and those in the cliff exposures. Water draining from OFG at $2.9 \mathrm{~m}$ depth in bore K3 was observed to seep from a planar bed of massive CBG mapped at $4 \mathrm{~m}$ depth along the donga face, coincident with the top of gravel talus filling the donga. It was also detected seeping from several OFG units exposed in the sea-cliff, focussed around depths of $3.3 \mathrm{~m}$ and $5.4 \mathrm{~m} \mathrm{bgl}$ (Figure 7). Seepage observed from the various exposures was broadly spread over a lateral distance spanning $28 \mathrm{~m}$, indicating significant lateral dispersion. The same OFG facies exposed $3.3 \mathrm{~m} \mathrm{bgl}$ on the sea-cliff also emitted water that was later injected to bore K9, confirming OFG in K9 must be interconnected with OFG in $\mathrm{K} 3$, if not directly, at least indirectly. A deeper vertical water transport component was detected in the test from $\mathrm{K} 9$, with the only other confirmed seepage point on the cliff face from this test being a cross-

\section{Discussion}

\section{Smoke and water tracers as indicators of interconnected OFG}

The primary objective of this study was to practically test the usefulness of smoke applied as a tracer for inferring how OFG are interconnected in alluvial gravel systems. Our findings reveal smoke can be used effectively for this purpose in unsaturated sediments, in situations where bores can be drilled and from which observations can be made. By recording both the relative time of smoke arrival and position of the discrete sets of OFG from which smoke was emitted in tests, we have succeeded in obtaining hard connectivity information for a small cross-section through the Canterbury Plains alluvial gravel aquifer.

We therefore suggest smoke tracing provides a complementary practical method to conventional stratigraphic mapping methods, i.e. graphic logging and supporting geophysics. The advantage of smoke tracing tests is they provide a means by which the dynamic connectivity of hydrofacies can be measured, i.e. information can be obtained about the physical processes of flow and transport, directly. Neither graphic logging nor geophysical methods provide such measurement. The information obtained from smoke tracing tests in this field investigation has potential to be applied in constraining the inverse problem of modelled fluid flow and transport through simulated 3D fields of the sedimentary deposits. This is something we aim to test in future work. 
343 In this initial practical trial, smoke tests were conducted on open bores. A practical problem with this 344 approach we have identified is the limited vertical resolution that can be achieved and difficulty in 345 accurately determining the connectivity of more than a single OFG layer. In a few cases, we did notice 346 smoke emission from layers of OFG at different depth horizons (e.g. bores K6 and K9 (Figure 6)). 347 However, in most instances smoke emission in tests was identifiable only from a single layer in any bore 348 - that layer being the most permeable OFG facies. Once the initial smoke emission clouded the bore, the 349 chance of making secondary observations from other OFG facies in the same bore was significantly reduced. This issue has implications for generating high spatial-resolution datasets using smoke, and also means the data we have collected is susceptible to false negative errors that we will need to address when applying it to inverse modelling problems. A possible improvement on the practical method demonstrated in this paper that would be useful to research is the practice of sealing off and testing discrete layers of OFG logged in the injection bore, using an inflatable packer device or similar. Using different coloured smoke sources to examine different facies connections also offers a way for expanding the number of observations permissible from a single test. Although this would not completely overcome the problem of clouded sight in the observational bores, it would enable some improved refinement of measurement, following the concepts of hydraulic tomography.

A similar technical issue of the smoke tracing method we have realised is that the lateral distances over which tracing is achievable during any individual test is restricted to the spacing of the observation bores. We noticed that bores immediately adjacent to the test bore act as a sink for the emitted smoke and create a barrier for further travel beyond. Similar issues apply to water when applied as a tracer, although we did record minor water seepage in bores beyond those immediately adjacent to the injection bore, as evidenced in Figure 7, results that were presumably influenced by gravitational drainage effects. The $5 \mathrm{~m}$ observational bore spacing we adopted in this field study was an arbitrary value, as also was the decision to use a $3 \times 3$ bore array. Assuming results are additive, in practice it would be possible to trace smoke and OFG connections over larger spatial scales by conducting multiple small-scale tests between many bores. The main obstacle for doing so, would be the resources required to do extensive drilling and conduct

As tracing elements that can be applied in advancing the study of heterogeneity of alluvial gravel systems under unsaturated conditions, smoke and water each exhibit contrasting physical properties that can be exploited, as witnessed in our field study. Obviously, there are significant mass differences between the two tracers and there was effectively no limit to the volume of water we were able to use in the tracing experiments. In contrast the amount of smoke that could be generated was limited by the technical specifications of the smoke machine and was a considerably smaller volume than the amount of water we injected. Whereas water demonstrated the advantageous quality of being traceable over longer distances, the gravitational forces that drive this lateral flow along any hydrostratigraphic plane equally exert a strong downward pull on the water, which one needs to be mindful of when interpreting results. At the other 
extreme, our smoke tracer results displayed no obvious signs of being strongly affected by gravity or density effects, which is a positive trait when studying small to medium scale lateral connectivity. This reduced potential energy however, coupled with the effects of gaseous diffusion and relative differences in practicable volumes of tracer that can be used, means total travel distances for smoke are much more limited than those of water.

Although we did not employ any geophysical methods in our field study, we recognise that it would have been a useful tool to use to infer detail of the static connectivity between mapped sedimentary features. Furthermore, we suspect that application of shallow, time-lapse geophysical methods at the time of the water tracing experiment, following the approaches described by Binley et al. (2015) and akin to those applied by Coscia et al. (2012) to map preferential flow zones in a shallow alluvial gravel aquifer, could potentially have yielded additional information on the dynamic connectivity of the OFG facies we observed. We postulate further research aimed at using hydrogeophysical methods to examine the dynamic connectivity of OFG in gravel outwash systems is warranted.

\section{Hydrofacies mapping and significance of clay-bound gravel}

The results from our tracing experiments provide a further example of the significant role OFG play as a hydrofacies in alluvial gravel aquifer systems. Relating the dynamic connectivities we observed from the smoke tracer tests to the braided alluvial architecture we mapped for the section of the Rakaia fan at Kyle, we associate the greatest hydraulic connectivity with planar OFG that we assume represent 'bar core' features that extend laterally and downstream over distances in excess of $15 \mathrm{~m}$. Significant connectivity is offered also via OFG in cross-stratified units we have interpreted to be bar margins that are predominantly aligned with the mean palaeoflow direction, as was revealed by the water tracing test that examined a larger volume of deposit. The water tracing test has revealed there is significant potential for horizontal flow along bedding planes of the Rakaia fan deposits yet, equally, there is definite vertical and horizontal connection between the layered packaged sets of OFG. We noticed that water discharging from the sea cliff during the water tracer test was not evenly spread across any one layer comprising OFG strata,

In the tracer tests we conducted we saw no evidence of either smoke or water transmitted via S or SG, which is of no surprise considering as hydrofacies they are orders of magnitude less permeable than OFG (Heinz \& Aigner, 2003; Lunt et al., 2004; Dann et al., 2009). Although we presumed CBG to be even less permeable than either SG or S, we did observe water seep from a unit we mapped as CBG on the donga face in a water tracer test (Figure 7). This result highlights limitations in our mapping methodology that was based on mainly visual assessment of texture to which is associated an inherent degree of subjectivity and uncertainty. In particular it demonstrates the difficulty of presuming CBG can be mapped as a discrete low permeability facies with accuracy. The difficulty arises from the issue of CBG being an altered state of what was formerly OFG. Consistent with the observations made by Dann et al. (2009), we 
noticed CBG often represented the lower portion of an OFG bed that had become progressively plugged, from the bottom up (e.g. Figure 3c). It is inevitable that associated with this progressive plugging is a progressive change in hydraulic properties that is hard to determine.

It is perhaps helpful to note that although we adopted the terminology CBG to describe the plugged OFG facies (CBG being a colloquial term used by local well drillers), the title is a bit of a misnomer. Because we failed to collect a representative bulk sample of what we mapped as CBG, we cannot confirm the exact clay content of this facies. Nonetheless, the PSD data of OFG facies that we distinctly noted on our bore records as being heavily coated with clay (but not plugged sufficiently to be classed as CBG) and which we assume represent a state nearing clay-bound, gives some information (Figure 3h). Based on these data, we predict clay most likely does make up the bulk of the mud $(<63 \mu \mathrm{m})$ fraction associated with CBG, although the presence of sand (that we measured to be between 5 and $17 \%$ of the sample weight) tends to indicate a continuum of grain sizes ranging from clay to sand are involved in the progressive plugging of the interstitial pore space of the OFG. Our interpretation is consistent with the observations of Dann at al. (2009), who describe the base of OFG lenses being interspersed with clay and more occasionally silt and fine sand.

Understanding the mode of formation of CBG was not the theme of our research, although some discussion of this topic is warranted since we conceive CBG to be implicated in hydrogeological function of alluvial gravel aquifers. We concur with the theorised mode of formation proposed by Cary (1951), Braden (1955) and Browne (2002), this being the mud component of CBG is a secondary deposit formed from percolation of water through OFG. We do not however believe CBG formation is necessarily restricted to hyporheic zone processes (which tend to be the focus of most study on the topic of postdepositional clogging of OFG) because, like Dann et al. (2009), we have witnessed muddy groundwater discharging from OFG exposed on the Canterbury sea-cliffs, after heavy rainfall or land irrigation events, far from any active river system. Also, turbid groundwater has been reported in several gravel aquifer systems in NZ, as a physical response to natural seismic activity (pers. comm. Konrad Weaver, Victoria University of Wellington, December 2016). These anecdotal observations of potential for active particulate transport by groundwater lead us to believe that CBG formation is a continually active internal process in relic alluvial fans, driven by groundwater flow and not necessarily confined to the unsaturated zone. The impact of such changes on the functionality of an aquifer system are difficult to gauge without an improved understanding of the rates and mechanisms by which CBG form and further investigation of this topic seems deserved.

Considering the lack of process-level understanding of CBG formation and its hydrogeological characteristics that we presume to be dynamic in nature, we are sceptical that CBG could ever be mapped predictively. From the results of our water tracing tests where water was observed to follow convoluted pathways around mapped CBG facies via interconnected OFG, we caution against making any generalised assumptions about CBG offering resistance to groundwater flow and contaminant 
transport at the scale associated with most water resource management problems in systems like the Canterbury Plains.

In total, we found CBG to constitute $11 \%$ (by volume) of the lithology mapped at Kyle and OFG accounted for $18 \%$. Based on our beliefs of how CBG likely forms, we infer that at the original time the alluvium at Kyle was deposited by the Rakaia River, the proportion of OFG in the fan material might well have been closer to $29 \%$. This content is within the range of $20-30 \%$ that Bridge \& Lunt (2006) report for braided river sedimentary systems. In previous studies made of surficial sediments of the Rakaia fan, OFG were never observed to comprise more than $5 \%$ of the lithology (Dann et al., 2008; 2009). Our latest observations made at Kyle, tend to indicate these were conservative estimates and OFG are likely to be a more abundant lithological component of the Rakaia fan than was previously determined.

\section{Implications for groundwater resource management}

Our research continues to be largely motivated by a need to improve predictive models used in groundwater resource management, for alluvial gravel aquifers in particular. The findings from the field experiments made at Kyle serve to highlight the significant role interconnected OFGs play on transmission of water and, by analogy, potential contaminants in alluvial outwash aquifer systems. A strong horizontal flow component in the vadose zone was observed through the water tracing experiment, as was notable non-uniform lateral dispersion, each of which raise questions over the reliability of simplified predictive models that assume contaminant plumes conform to a simple Gaussian distribution, as routinely applied in resource management decision making (in NZ at least).

The horizontal anisotropy ratio we calculated at Kyle, based on the first arrival times of smoke in tracing experiments, is quite a high value. It assumes the $600 \mathrm{~m}^{3}$ volume of heterogeneous fan deposit examined can be modelled as a uniform, 2D anisotropic system, which is a gross simplifying assumption, albeit one routinely applied in groundwater resource management modelling problems in NZ. High anisotropy ratios are to be expected in cases where heterogeneous channelised aquifer systems are reduced to simple lumped models and as Zappa et al. (2006) concluded, the ratio is sensitive to the connectivity of OFG hydrofacies present within the representative elementary volume. Nonetheless, the ratio of 6 we determined is significantly higher than the ratio of 1.62 Quiñones-Aponte (1989) reports as a realistic ratio for stream-laid alluvial deposits and inferred from pump test analyses, or the range of 1.1 - 1.7 Zappa et al. (2006) report for a model block of a gravel-bed braided river deposit and determined from geostatistical facies simulations informed by descriptive methods. There are few aquifer pump test results that have been published for the Canterbury Plains aquifer system by which to make comparisons, although a ratio of 2 is inferable from pump test results presented by McEwan (2001). Being based on first arrival time, it is feasible the horizontal anisotropy ratio we have calculated using Eqth (3) provides an over estimate of the true anisotropy ratio, because it does not factor in layered heterogeneity (Domenico \& Schwartz, 1990). Rather than critique the value of $\alpha$ we determined, we prefer to argue it provides weight to the argument that research effort should be directed to development of 3D groundwater models that realise aquifer 
heterogeneity and connectivity of OFG, which can be applied as tools to examine the predictive uncertainty of decisions made in groundwater resource management.

The rate at which each smoke and water were observed to transmit through the OFG sediments at Kyle clearly demonstrated the ease with which solutes can be transported through outwash gravel systems, from which it was easy to gain an appreciation for why gravel aquifers rank so low in their ability to offer effective removal of microbial contaminants (Pang, 2009). To illustrate this as a problem, we refer to regional planning rules set for Canterbury, NZ that require the vertical separation distance between a septic tank effluent drainage field and the water table is at least $1 \mathrm{~m}$, together with a minimum of $50 \mathrm{~m}$ horizontal separation distance between the effluent disposal area and a water supply well (Canterbury Regional Council, 2015, rule 5.7-5.8). These distances are stipulated based on the aim of protecting human health from pathogenic disease, based largely on perceived risk and in which the probability of OFG being present is not explicitly factored. From directly observing the interconnectedness of OFG over the scale of tens of metres in the field at Kyle, we are prompted to question how protective the separation distances applied to on-site wastewater treatment systems in Canterbury are.

Our intention is to apply the Kyle experimental dataset to mathematical groundwater modelling exercises that will study scaling issues in hydrogeological problems and to purposefully examine the limitations of conventional simplified modelling assumptions applied in resource management of the Canterbury Plains aquifer.

\section{Conclusion}

From the field study we have made on a 3D model section of Quaternary alluvial outwash deposits of the Rakaia fan at Kyle, we conclude:

(i) smoke tracing experiments are a viable practical method for inferring knowledge about the dynamic connectivity of OFG facies in gravel-bed braided alluvium and, as a practical tool, complement conventional practical field methods, such as lithological mapping and geophysics.

(ii) alluvial gravel aquifers are highly anisotropic and heterogeneous, and most groundwater flow (and in turn, contaminant transport) is concentrated along OFG facies.

\section{Acknowledgements}

Funding for this project was from the New Zealand Ministry of Business, Innovation and Employment contract number C03X1001. We thank staff at Dairy Holdings Ltd for allowing access to the Kyle site and providing assistance with the water tracing experiments. We are also grateful to the journal reviewers who 
536

537

538

539

540

541

542

543

544

545

546

547

548

549

550

551

552

553

554

555

556

557

558

559

560

561

562

563

564

565

566

567

568

569

570

571

572

573

574

\section{References}

Anderson, M.P., Aiken, J.S., Webb E.K. \& Mickelson, D.M. 1999. Sedimentology and hydrogeology of two braided stream deposits. Sedimentary Geology, 129 (3), 187-199.

Anketell, J.M. \& Rust, B.R. 1990. Origin of cross-stratal layering in fluvial conglomerates, Devonian Malbaie Formation, Gaspé, Quebec. Canadian Journal of Earth Sciences, 27 (12), 1773-1782, http://doi.org/10.1139/e90-183

Ashworth, P.J., Best, J.L., Peakall, J. \& Lorsong, J.A. 1999. The influence of aggradation on braided alluvial architecture: field study and physical scale-modelling of the Ashburton River gravels, Canterbury Plains, New Zealand. In: Smith, N.D. \& Rogers, J. (eds) Fluvial Sedimentology VI. Special Publication of the International Association of Sedimentologists, 28, 333-346.

Bal, A.A. 1996. Valley fills and coastal cliffs buried beneath an alluvial plain: evidence from variation of permeabilities in gravel aquifers, Canterbury Plains, New Zealand. Journal of Hydrology (New Zealand), 35 (1), 1-27.

Bayer, P., Huggenberger, P., Renard, P. \& Comunian, A. 2011. Three-dimensional high resolution fluvioglacial aquifer analog: Part 1: Field study. Journal of Hydrology, 405, 1-9, http://doi.org.10.1016/j.jhydrol.2011.03.038

Berger, G.W., Tonkin, P.J. \& Pillans, B.J. 1996. Thermoluminescence ages of post-glacial loess, Rakaia River, South Island, New Zealand. Quaternary International, 34-36, 177-181.

Binley, A., Hubbard, S., Huisman, J.A, Revil, A., Robinson, D.A., Singha, K. \& Slater, L.D. 2015. The emergence of hydrogeophysics for improved understanding of subsurface processes over multiple scales. Water Resources Research, 51 (6), 3837-3866, http://doi.org/10.10002/2015WR017016

Braden G.E. 1955. Openwork Gravel Deposits in Stream Valleys. Proceedings of the Oklahoma Academy of Science for 1955, 88-89.

Bridge, J.S. \& Lunt, I.A. 2006. Depositional models of braided rivers. In: Sambrook Smith, G.S., Best, J.L, Bristow, C.S. \& Petts, G.E. (eds) Braided Rivers: process, deposits, ecology and management. Blackwell, Oxford, 11-50.

Brown, L. 2001. Canterbury. In: Rosen, M.R. \& White, P.A. (eds) Groundwaters of New Zealand. The New Zealand Hydrological Society, Wellington, 441-459.

Browne, G.H. 2002. A large-scale flood event in 1994 from the mid-Canterbury Plains, New Zealand, and implications for ancient fluvial deposits. In: Martini, I.P., Baker, V.R. \& Garzon, G. (eds) Flood and Megaflood Processes and Deposits: Recent and Ancient Examples. International Association of Sedimentologists, Special Publications, 32, 99-109.

Browne, G.H. \& Naish, T.R. 2003. Facies development and sequence architecture of a Late Quaternary fluvial-marine transition, Canterbury Plains and Shelf. Sedimentary Geology, 158 (1/2), 57-86, http://doi.org/10.1016/S0037-0738(02)00258-0

Canterbury Regional Council (2015). Canterbury Land and Water Regional Plan: volume 1, http://files.ecan.govt.nz/public/lwrp/LWRP-Plan-Volume 1.pdf (accessed 29 August 2016)

Carle, S.F. \& Fogg, G.E. 1996. Transition probability-based indicator geostatistics. Mathematical Geology, 28 (4), 453-477, http://doi.org/10.1007/BF02083656 
Carle, S.F., Labolle, E. M., Weissmann, G.S., Van Brocklin, D. \& Fogg, G.E. 1998. Conditional simulation of hydrofacies architecture: a transition probability/Markov approach. In: Fraser, G.S. \& Davis, J.M. (eds) Hydrogeological Models of Sedimentary Aquifers: Society for Sedimentary Geology (SEPM) Special Publication, Concepts in Hydrogeology and Environmental Geology No. 1, 147-170.

Carling, P.A. 1996. Morphology, sedimentology and palaeohydraulic equivalence of large gravel dunes, Altai Mountains, Siberia. Sedimentology, 43, 647-664.

Carling, P. \& Glaister, M.S. 1987. Rapid deposition of sand and gravel mixtures downstream of a negative step: The role of matrix-infilling and particle-overpassing in the presence of bar-front accretion. Journal of the Geological Society, 144 (4), 543-551, http://doi.org/10.1144/gsjgs.144.4.0543

Cary, A.S. 1949. Natural clay grout in openwork gravel. Geological Society of America Bulletin 60 (12), Part 2, 1878-1879.

Cary, A.S. 1951. Origin and significance of openwork gravel. Transactions of the American Society Civil Engineers 116, 1296-1318.

Clifton, H.E. 1973. Pebble segregation and bed lenticularity in wave-worked versus alluvial gravel. Sedimentology, 20, 173-187 http://doi.org/10.1111/j.1365-3091.1973.tb02043.x

Close, M.E., Nobes, D.C. \& Pang, L. 2004. Presence of preferential flow paths in shallow groundwater systems as indicated by tracer experiments and geophysical surveys. In: Bridge, J.S. \& Hyndman, D.W. (eds) Aquifer Characterization. Society for Sedimentary Geology, Special Publications, 80, 79-91.

Close, M.E., Pang, L. Flintoft, M.J. \& Sinton, L.W. 2006. Distance and flow effects on microsphere transport in a large gravel column. Journal of Environmental Quality, 35, 1204-1212, http://doi.org. 10.2134/jeq2005.0286

Close M.E., Dann, M.E., Flintoft, M. Havelaar, P. \& Peterson, M. 2011. A novel method for sampling and characterizing unconsolidated deep vadose zones, Vadose Zone Journal, 11 (2), http://doi.org/10.2136/vzi2011.0113

Coscia, I., Linde, N., Greenhalgh, S. \& Green A. 2012. Estimating traveltimes and groundwater flow patterns using 3D time-lapse crosshole ERT imaging of electrical resistivity fluctuations induced by infiltrating river water. Geophysics, 77 (4), 239-250.

Dann R., Close M.E., Pang, L., Flintoft, M.J., \& Hector, R. 2008. Complementary use of tracer and pumping tests to characterize a heterogeneous channelized aquifer system in New Zealand. Hydrogeology Journal, 16, 1177-1191, http://doi.org./10.1007/s10040-008-0291-4

Dann R., Close M.E., Flintoft M.J., Hector, R., Barlow, H., Thomas, S. \& Francis, G. 2009. Characterization and estimation of hydraulic properties in an alluvial gravel vadose zone. Vadose Zone Journal, 8 (3), 651-663, http://doi.org/10.2136/vzi2008.0174

Domenico, P.A. \& Schwartz, F.W. 1990. Physical and Chemical Hydrogeology. John Wiley \& Sons, New York.

Elfeki, A.M.M \& Dekking, F.M. 2005. Modelling subsurface heterogeneity by coupled Markov chains: directional dependency, Walther's Law and entropy. Geotechnical and Geological Engineering, 23 (6), 721-756. 
Ferreira, J.T., Ritzi, R.W. \& Dominic, D.F. 2010. Measuring the permeability of open-framework gravel. Ground Water, 48 (4), 593-597.

Fleming, R.J. \& Bradshaw, S.H. 1992. Detection of macropores using smoke. Canadian Society of Agricultural Engineering, 92, 1-9.

Flynn, R.M., Mallen, G., Engel, M., Ahmed, A. \& Rossi., P. 2015. Characterizing aquifer heterogeneity using bacterial and bacteriophage tracers. Journal of Environmental Quality, 44 (5), 1448-1458, http://doi.org/10.2134/jeq2015.02.0117

Fox, G.A., Marvin, M.M., Guzman, J.A., Hoang, C.K., Malone, R.W. \& Kanwar, R.S. 2012. E. coli transport through surface-connected biopores identified from smoke injection tests. Transactions of the American Society of Agricultural and Biological Engineers, 55 (6), 2185-2194.

Gershenzon, N.I., Soltanian1, M.R., Ritzi Jr., R.W., Dominic, D.F., Keefer, D., Shaffer, E., Storsved, B. 2015. How does the connectivity of open-framework conglomerates within multi-scale hierarchical fluvial architecture affect oil sweep efficiency in waterflooding? Geosphere, 11 (6), 2049-2066, http://doi..org/10.1130/GES01115.1

Gibb, J.G. 1978. Rates of coastal erosion and accretion in New Zealand. New Zealand Journal of Marine and Freshwater Research, 12, 429-456.

Hansen, A. L., Gunderman, D. \& He, X. 2014. Uncertainty assessment of spatially distributed nitrate reduction potential in groundwater using multiple geological realizations. Journal of Hydrology, 519, Part A: 225-237, http://doi.org/10.1016/j.jhydrol.2014.07.013

Heinz, J. \& Aigner, T. 2003. Hierarchical dynamic stratigraphy in various quaternary gravel deposits, Rhine glacier area (SW Germany): implications for hydrostratigraphy. International Journal of Earth Sciences, 92, 923-938, http://doi.org/10.1007/s00531-003-0359-2

Heinz, J., Kleineidam, S., Teutsch, G. \& Aigner T. 2003. Heterogeneity patterns of Quaternary glaciofluvial gravel bodies (SW-Germany): application to hydrogeology. Sedimentary Geology, 158 (1-2), 1-23, http://dx.doi.org/10.1016/S0037-0738(02)00239-7

Huggenberger, P. \& Regli, C. 2006. A sedimentological model to characterize braided river deposits for hydrogeological applications. In: Sambrook Smith, G.S., Best, J.L, Bristow, C.S. \& Petts, G.E. (eds) Braided Rivers: process, deposits, ecology and management. Blackwell, Oxford, 51-74.

Ikeda, K. (1982) An experimental study of the formation of openwork gravel layers under alluvial-flow conditions. Transactions of the Japanese Geomorphological Union, 3, 57-65.

Jussel, P., Stauffer, F. \& Dracos, T. 1994. Transport modeling in heterogeneous aquifers: 1. Statistical description and numerical generation of gravel deposits. Water Resources Research, 30, 1803-1817.

Klingbeil, R., Kleineidam, S., Asprion, U., Aigner, T. \& Teutsch, G. 1999. Relating lithofacies to hydrofacies: outcrop-based hydrogeological characterisation of Quaternary gravel deposits. Sedimentary Geology, 129 (3), 299-310.

Koltermann, C.E. \& Gorelick, S.M. 1996. Heterogeneity in sedimentary deposits: A review of structureimitating, process-imitating, and descriptive approaches. Water Resources Research, 32 (9), 26172658, http://doi.org/ 10.1029/96WR00025 
Leckie, D.A. 1994. Canterbury Plains, New Zealand: Implications for sequence stratigraphic models. American Association of Petroleum Geologists (AAPG) Bulletin, 78 (8), 1240-1256.

Leckie, D.A. 2003. Modern environments of the Canterbury Plains and adjacent offshore areas, New Zealand - an analog for ancient conglomeratic depositional systems in nonmarine and coastal zone settings. Bulletin of Canadian Petroleum Geology, 51 (4), 389-425, http://doi.org/10.2113/51.4.389

Lunt, I.A., Bridge, J.S. \& Tye R.S. 2004. Development of a 3D depositional model of braided river deposits. In: Bridge, J.S. \& Hyndman, D.W. (eds) Aquifer Characterization. Society for Sedimentary Geology, Special Publications, 80, 39-169.

Lunt, I.A. \& Bridge, J.S. 2007. Formation and preservation of open-framework gravel strata in unidirectional flows. Sedimentology, 54 (1), 71-87, http://doi.org/10.1111/j.1365-3091.2006.00829.x

Maghrebi, M., Jankoyic, I., Weissmann, G.S., Shawn Matott, L., Allen-King, R.M. \& Rabideau, A.J. 2015. Contaminant tailing in highly heterogeneous porous formations: Sensitivity on model selection and material properties. Journal of Hydrology, 531 (1), 149-160, http;//doi.org/10.1016/j.jhydrol.2015.07.015

\begin{abstract}
Margat, J. \& van der Gum, J. 2013. Groundwater around the World: A Geographic Synopsis. CRC Press,
\end{abstract} Boca Raton, 47-49.

McEwan, G. 2001. The Hydrogeology of the Orari River Shallow Aquifer. MSc thesis, University of Canterbury, New Zealand.

Milanović, P.T. 2010. Aeration zone in karst - properties and investigations. In: Andrea, B., Carrasco, F., J.J. Durán \& LaMoreaux, J.W. (eds) Advances in Research in Karst Media. Springer, Heidelberg, 423428, http://doi.org/10.1007/978-3-642-12486-0

Newnham, R.M., Lowe, D.L., Williams, P.W. 1999. Quaternary environmental change in New Zealand: a review. Progress in Physical Geography, 23, 567-610.

Pang, L. \& Close, M.E. 1999. Field-scale physical non-equilibrium transport in an alluvial gravel aquifer. Journal of Contaminant Hydrology, 38, 447-464.

Pang, L. 2009. Microbial removal rates in subsurface media estimated from published studies of field experiments and large intact soil cores. Journal of Environmental Quality, 38 (4), 1531-59, http://doi.org/10.2134/jeq2008.0379

Quiñones-Aponte, V. 1989. Horizontal anisotropy of the principal groundwater flow zone in the Salinas alluvial fan, Puerto Rico. Groundwater, 27 (4), 491-500.

Ramos, A. \& Sopeña, A. 1983. Gravel bars in low-sinuosity streams (Permian and Triassic, central Spain). In: Collinson, J.D. \& Lewin, J. (eds) Modern and Ancient Fluvial Systems. Special Publication, International Association of Sedimentologists, 6, 301-312.

Regli, C. Huggenberger, P. \& Rauber, M. 2002. Interpretation of drill core and georadar data of coarse gravel deposits. Journal of Hydrology, 255, 234-252.

Renard, P. \& Allard, D. 2013. Connectivity metrics for subsurface flow and transport. Advances in Water Resources, 51, 168-196.

Rossi, P., De Carvaldho-Dill, A., Muller, I. \& Aragnom, M. 1994. Comparative tracing experiments in a porous aquifer using bacteriophages and a fluorescent dye on a test field located at Wilerwald 
(Switzerland) and simultaneously surveyed on a local scale by radio-magneto-tellury (12-240 kHz). Environmental Geology, 23, 192-200.

Rowan A.V., Roberts, H.M., Jones, M.A., Duller, G.A.T., Covery-Crump S.J. \& Brocklehurst S.H. 2012. Optically stimulated luminescence dating of glaciofluvial sediments on the Canterbury Plains, Quaternary Geochronology, 8, 10-22, http://doi.org/10.1016/i.quageo.2011.11.013

Rust, B.R. 1984. Proximal braidplain deposits in the Middle Devonian Malbaie Formation of Eastern Gaspe, Quebec, Canada. Sedimentology, 31, 675-696.

Siegenthaler, C. \& Huggenberger, P. 1993. Pleistocene Rhine gravel: deposits of a braided river system with dominant pool preservation. In: Best, J.L. \& Bristow, C.S. (eds) Braided Rivers. Geological Society Special Publication, 75, 147-162.

Sinton, L.W., 1980. Two antibiotic resistant strains of Escherichia coli for tracing the movement of sewage in groundwater. Journal of Hydrology (New Zealand), 19, 119-130.

Smith, N.D. 1974. Sedimentology and bar formation in the upper Kicking Horse River: a braided meltwater stream.Journal of Geology 82, 205-223.

Steel, R.J. \& Thompson, D.B. 1983. Structures and textures in Triassic braided stream conglomerates ('Bunter' Pebble Beds) in the Sherwood Sandstone Group, North Staffordshire, England. Sedimentology, 30, 341-367.

Taucer, P. 2005. Development of Smoke Tracer Instrument for Groundwater Recharge Investigation in the Edwards Aquifer Region: Smoke Tracer System Design. Report prepared for the Department of Biological and Agricultural Engineering, Texas A\&M University, http://twri.tamu.edu/docs/funding/usgs/2004-05/taucer final report.pdf

Tonkin, P.J., Runge, E.C.A. \& Ives, D.W. 1974. A study of Late Pleistocene loess deposits, South Canterbury, New Zealand. Quaternary Research, 4, 217-231.

Weissmann, G.S., Pickel, A., McNamara, K.C., Frechette, J.D., Kalinovich, I. Allen-King, R.M. \& Jankovic, I. 2015. Characterization and quantification of aquifer heterogeneity using outcrop analogs at the Canadian Forces Base Borden, Ontario, Canada. Geological Society of America Bulletin, 127 (7-8), 1021-1035.

Zappa, G., Bersezio, R., Felletti, F., Guudici, M. 2006. Modeling heterogeneity of gravel-sand braided stream, alluvial aquifers at the facies scale. Journal of Hydrology, 325, 134-153, http://doi.org/10.1016/j.hydrol.2005.10.016

Zekster, I.Z. \& Everett, L.G. 2004. Groundwater Resources of the World and Their Use. UNESCO International Hydrology Programme-VI, series on groundwater, 6, http://unesdoc.unesco.org/images/0013/001344/134433e.pdf 


\section{Fig. 1}

2 Location map for the Canterbury Plains, South Island, New Zealand. The position of the Kyle field-site and

3 four major alpine rivers whose coalesced fans form the Plains are shown. Approximate extent of the

4 Rakaia fan, as determined from topographic and lithological evidence, is highlighted in green.

\section{Fig. 2}

7 Outcrop photo and interpretative sketch of the Kyle site. The figure shows the distribution of the four 8 textural classes with respect to their site of deposition within the braided river system. Labels on the 9 sketch correspond to the depositional niches and features described in the text. BC = bar core, $\mathrm{BT}=$ bar 10 top, $\mathrm{BM}=$ bar margin, $\mathrm{CF}=$ channel fill, sf = slip face, la = lateral accretion surface associated with bar 11 margin or dune, $\mathrm{sd}=$ sand drape on bar margin. The cliff face is perpendicular to the palaeoflow direction.

\section{$13 \quad$ Fig. 3}

14 Photographic examples (a-d) of the four textural classes assumed in this study. Measured particle size distributions (PSDs) for three of the four major facies are shown alongside (e-h). PSD data were not obtained for clay-bound gravel (an image of which is provided in (d)). The PSD curves of OFG that were noted as being heavily clay-coated but not necessarily 'clay-bound' (h) are plot separate from clean OFG (g). Note: Cobble-sized clast fractions were not measured, and these grain sizes are incorporated with measured gravel fraction.

\section{Fig. 4}

Downhole photos of smoke tracer test set-up. Smoke machine suspended down sealed test bore, providing smoke source (a). Smoke emitting from OFG facies $(2.8 \mathrm{~m} \mathrm{bgl})$ in open observation bore (b). White arrows mark relative magnitude of observed smoke emission.

\section{Fig. 5}

Transition probability (TP) matrix showing juxtapositional tendencies of textural classes along the mean palaeoflow (x-) direction on the Rakaia fan at Kyle (a); transverse to the fan (y-direction) (b), and in the vertical (z-) direction (c). In (c) dot symbols represent field measurements from logged vertical transects. For both horizontal directions (b) and (c), measured data represent embedded transition probabilities that were derived from those in (a) and assuming Walther's Law. Solid line symbolises best-fit Markov chain TP model. Plots on the diagonal denote auto-transitions between the same textural class. The sills in such cases represent volumetric proportion of textural class. Plots off the diagonal denote cross-transitions between different textural classes, i.e. tendency to occur adjacent to each other. Codes for the textural classes S, OFG, SG and CBG are defined in the main text. 


\section{Fig. 6}

38 Connected OFG facies, as determined from smoke tracer tests conducted from bores $\mathrm{K} 2$, K5 and K8.

39 Dashed lines indicate inferred connection between discrete facies. Line thickness scales proportionately 40 with estimated relative hydraulic conductivity $K^{*}$, which was derived from measured smoke arrival times.

41 For clarity the other key textural classes have been omitted, see Figure 2 for complete picture of mapped 42 textural classes.

\section{Fig. 7}

45 Connected hydro-facies, as determined from water injection tests conducted from bores K3 and K9. 46 Dashed lines indicate inferred hydraulic connection between discrete facies. Line thickness scales 47 proportionately with estimated relative hydraulic conductivity $K^{*}$, derived from measured times at which 48 seepage was observed to start. Note: water drained under gravity. Also, in some cases water was 49 observed to seep from CBG facies, hence CBG are plot together with OFG (which was the main active 50 hydro-facies). Square symbols mark respective points of water injection in bores K3 and K9. SG and S 51 textural classes have deliberately been omitted, see Figure 2 for complete picture of mapped textural 52 classes. 


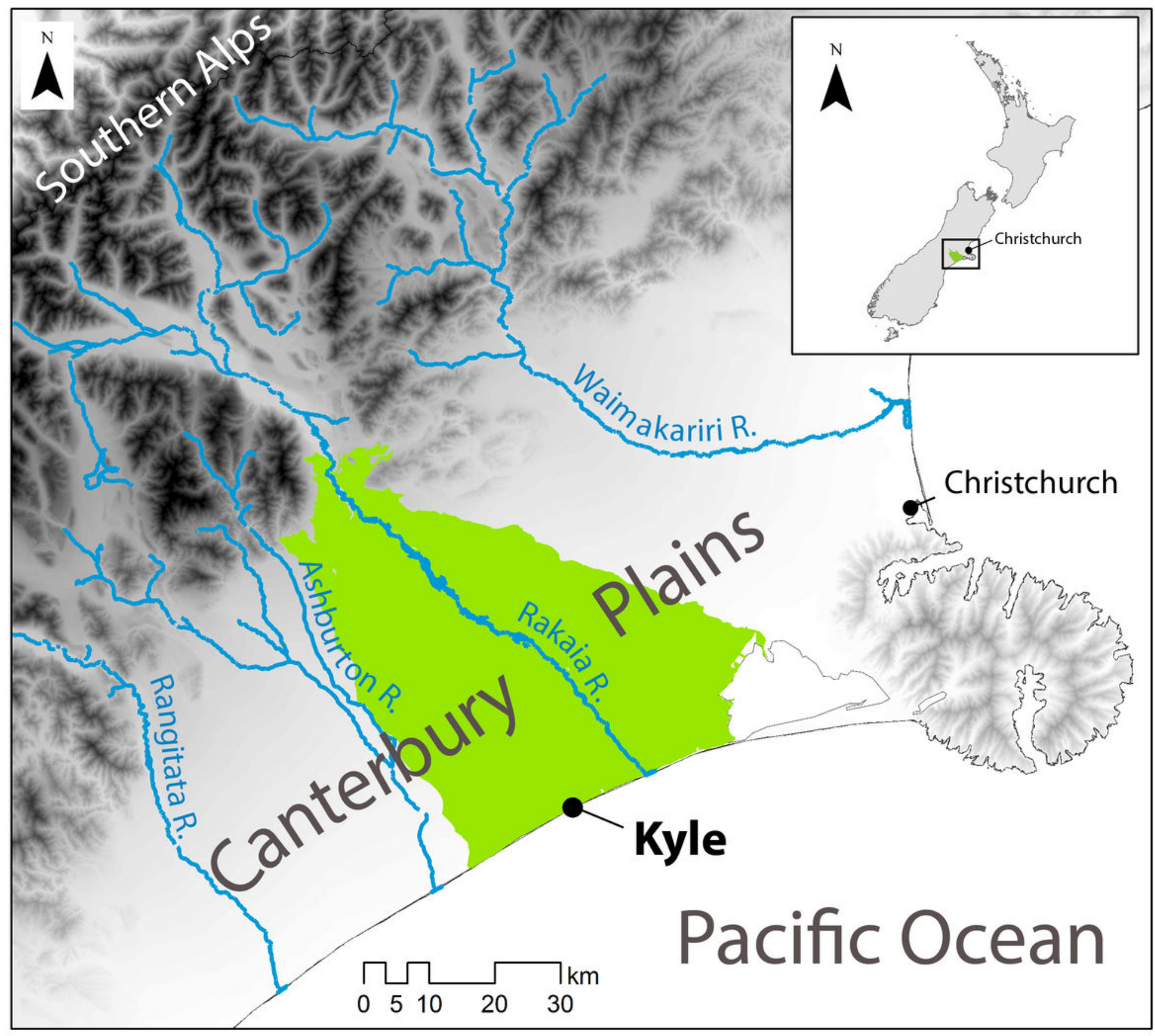




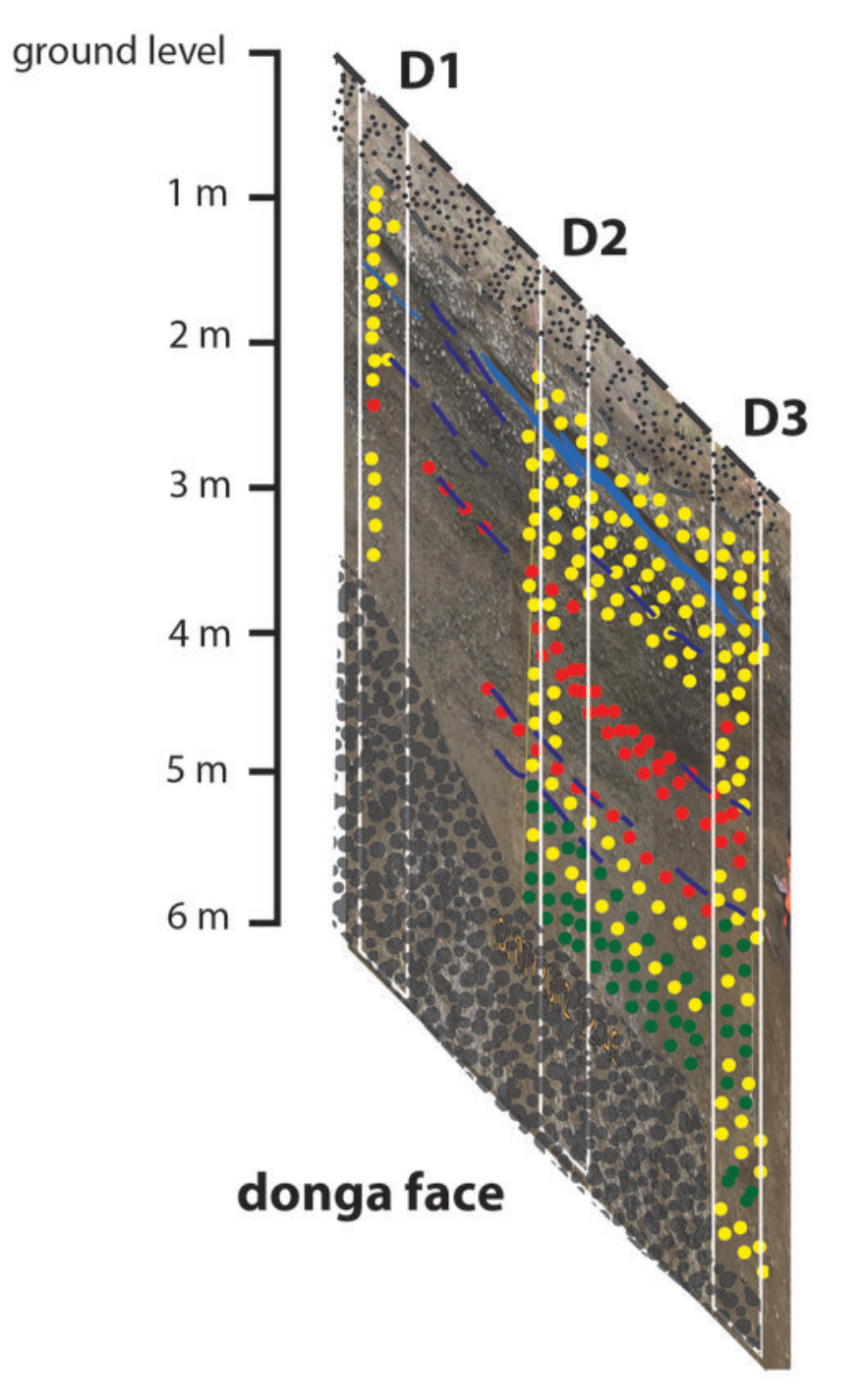

LEGEND:

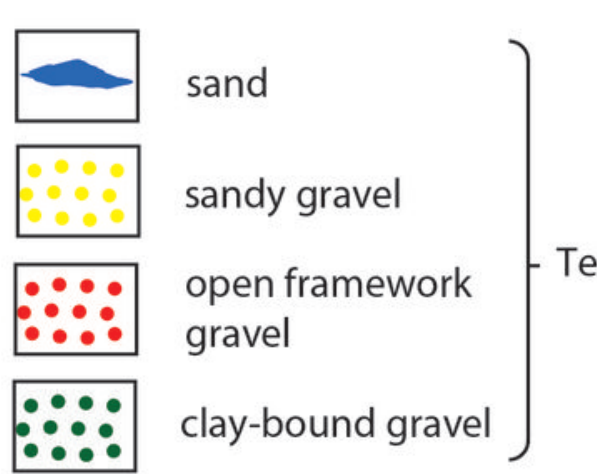

boreholes

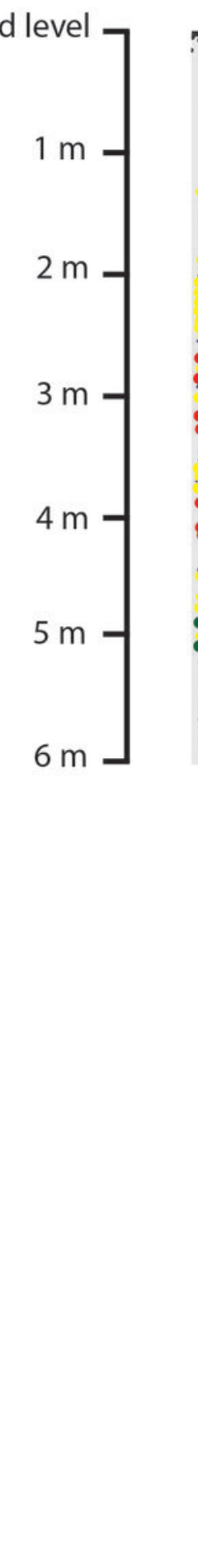

boreholes

F4

$\checkmark$

$=\overbrace{}^{K 5}$

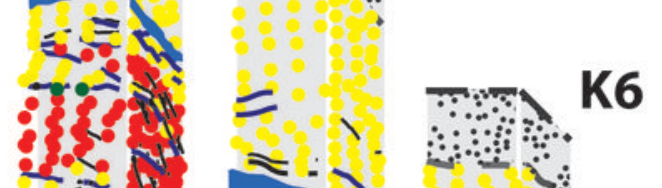

as =-1

劉

क. . 1

in

s.

?

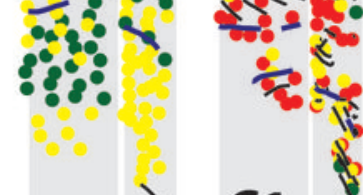

C1
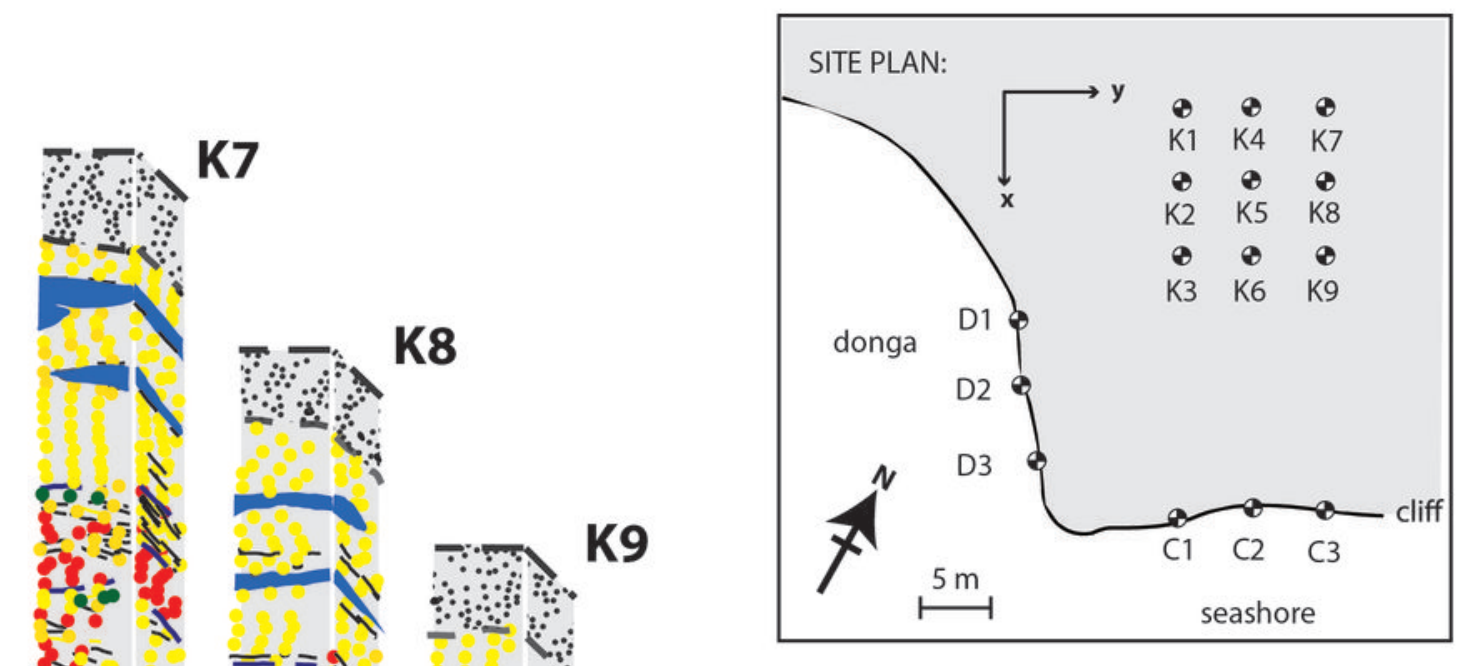

ta $=-1$

\%: $:$ :

in:

20.040

$\because \leqslant-3$.

$1 \mathrm{~m} \searrow_{z} \stackrel{1 \mathrm{~m}}{\mathrm{y}}$

(mean palaeoflow direction)
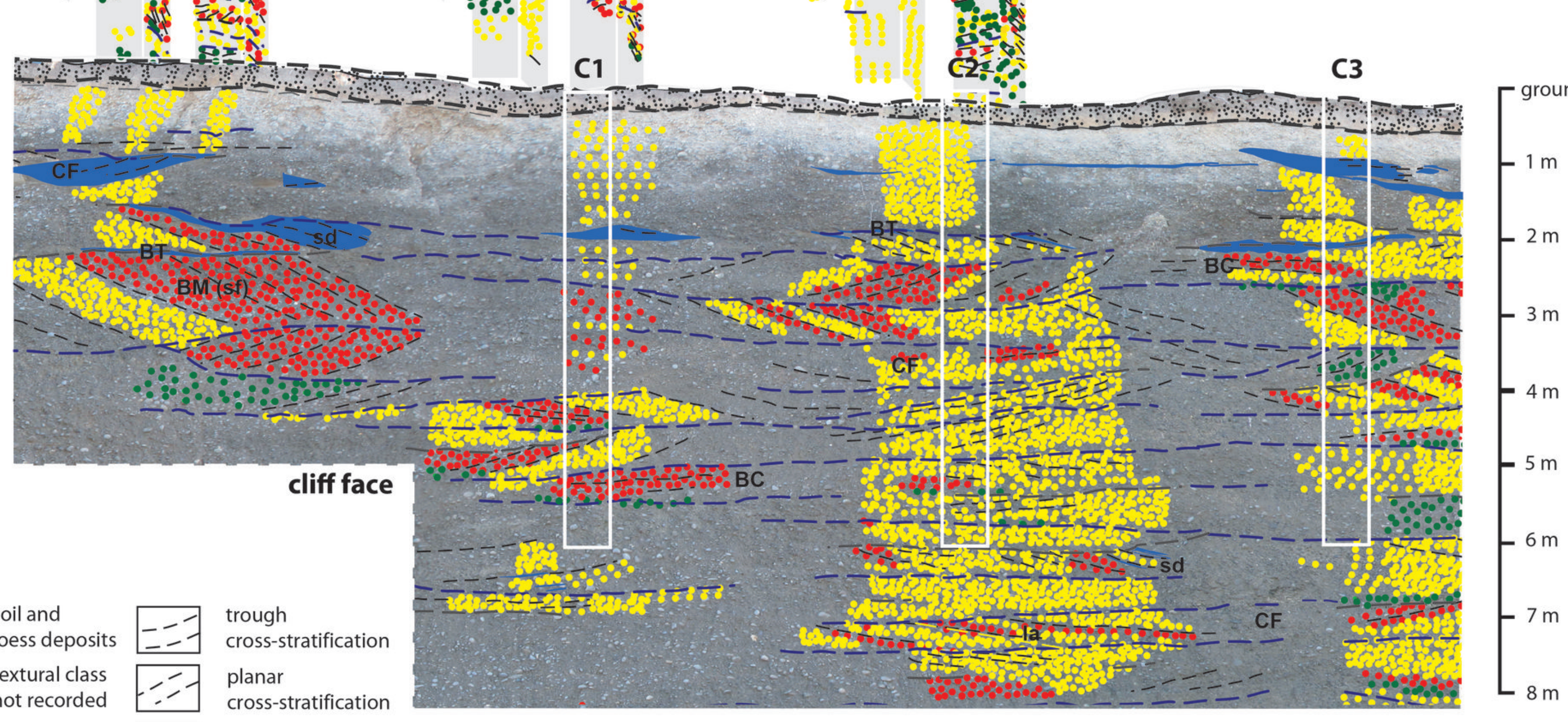

talus bounding (erosion) surface 


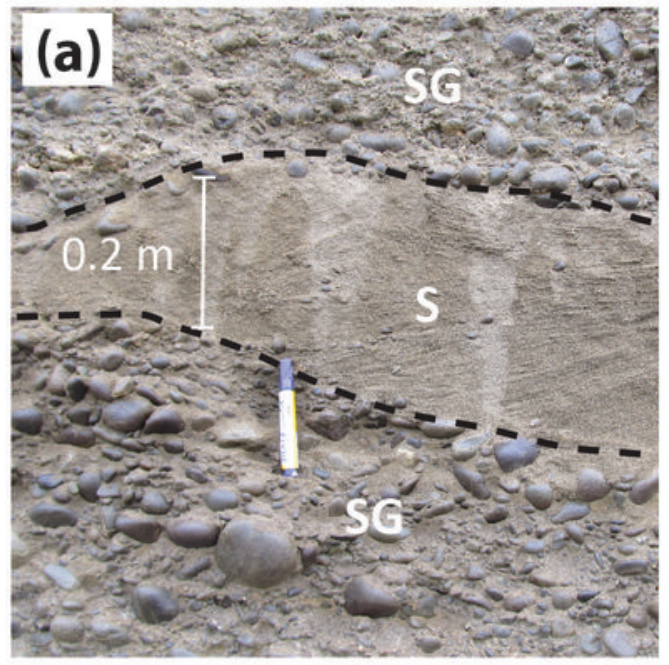

(e)

Sand (S)
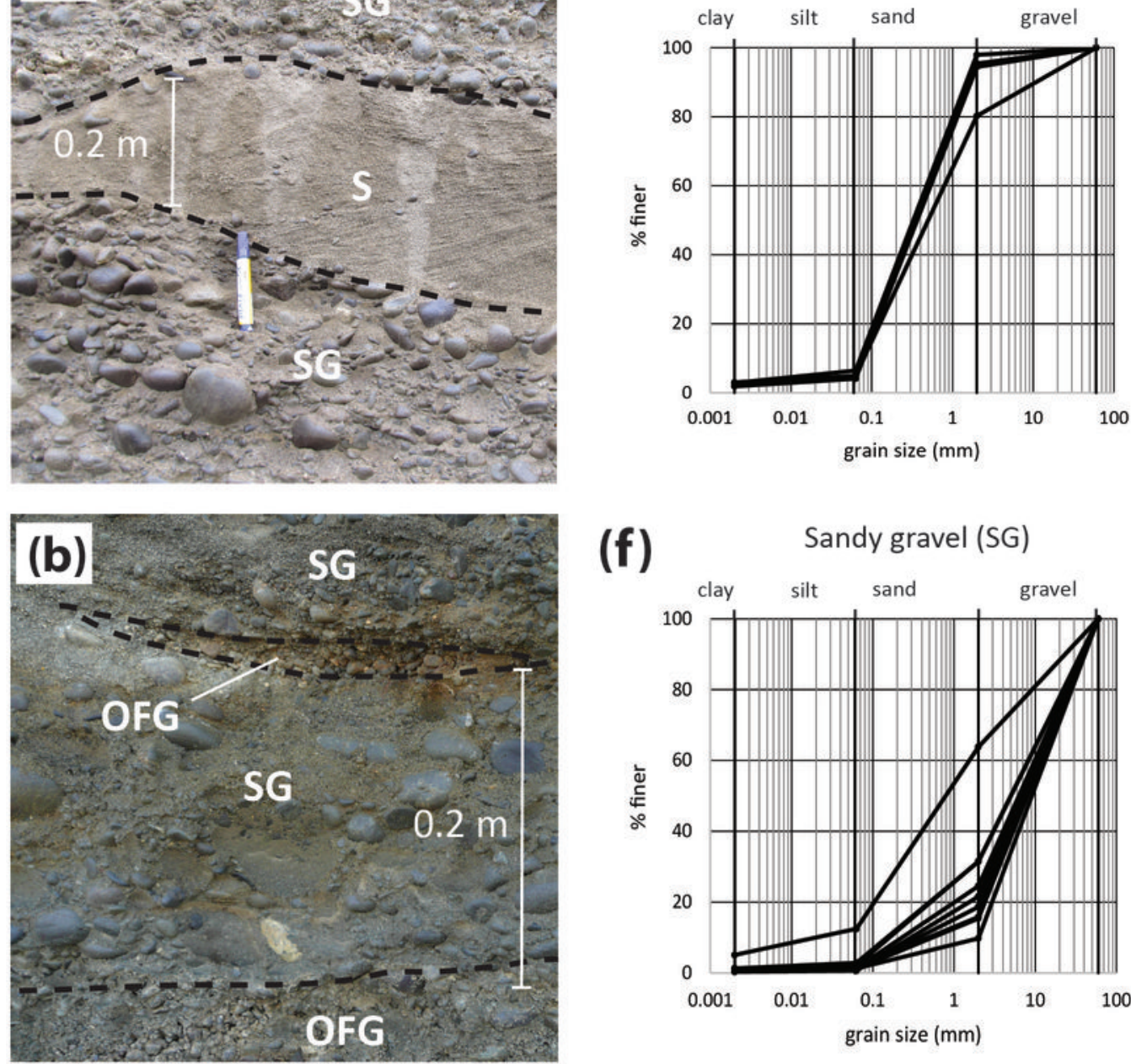

(f)

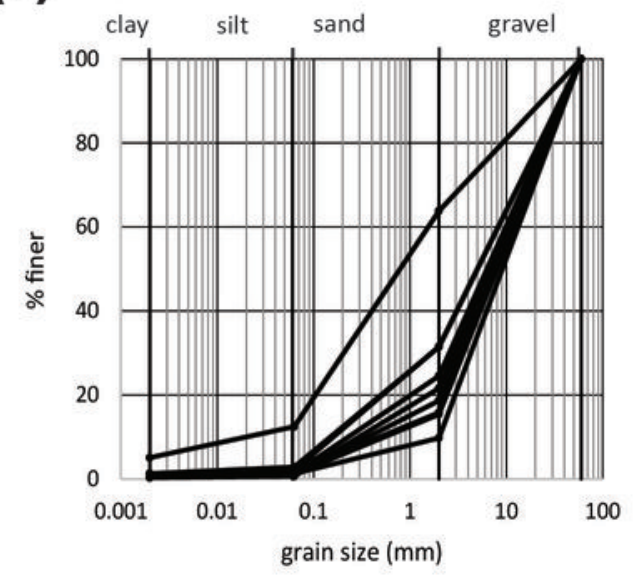

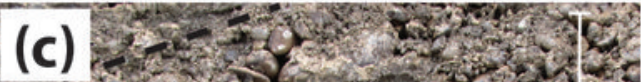

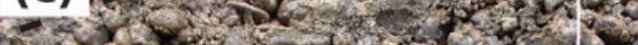

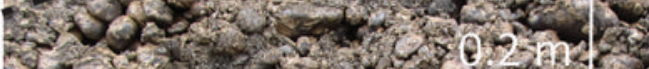

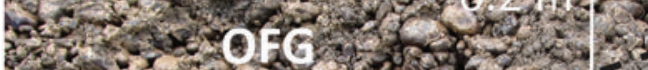

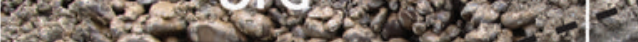

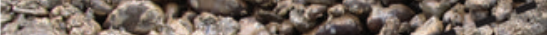

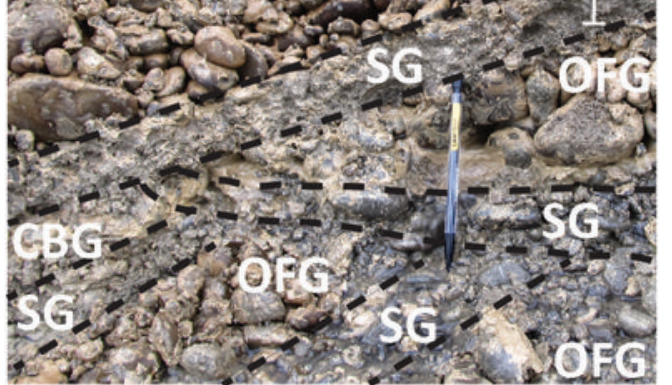

(g) Open framework gravel (OFG)
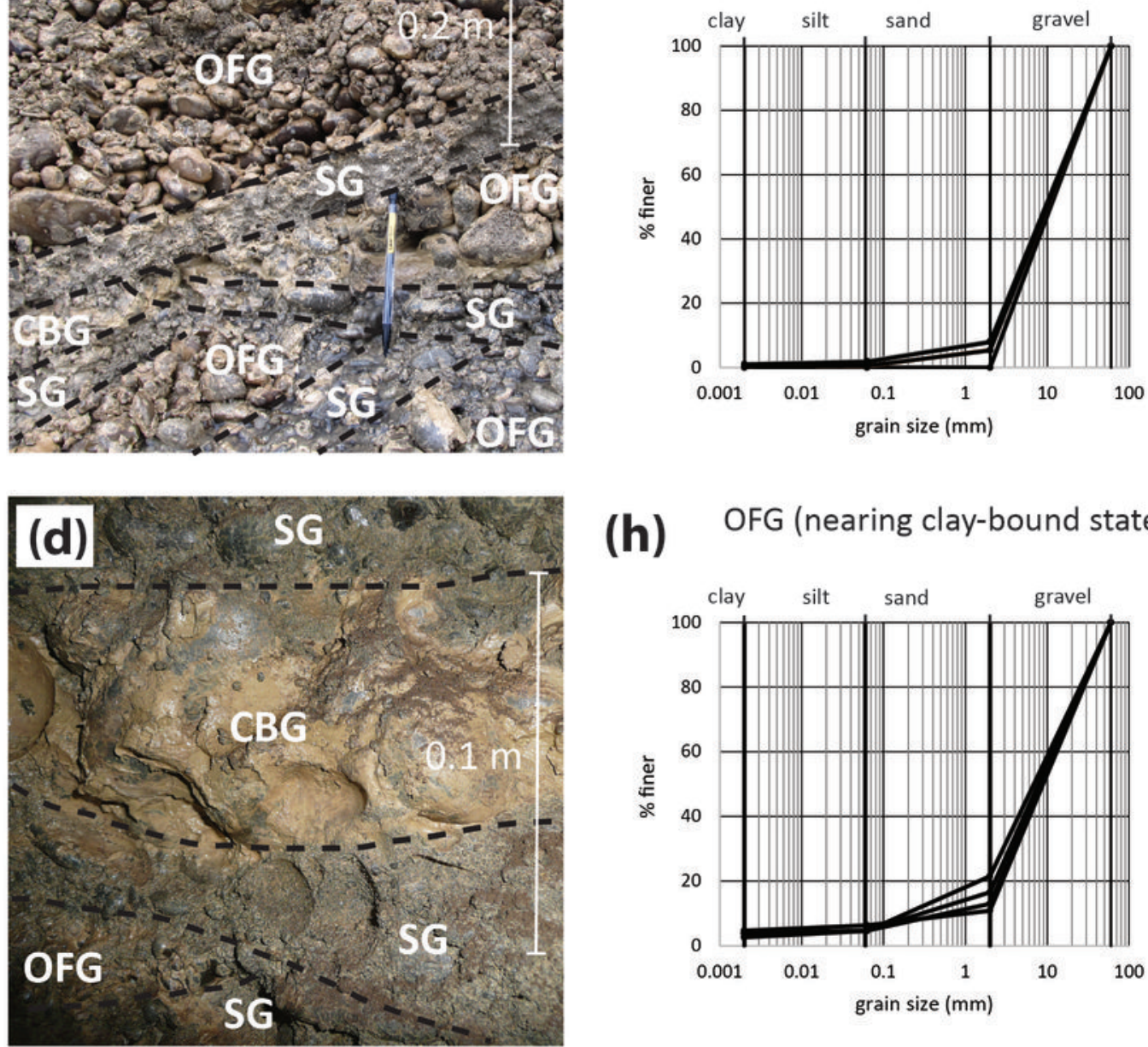

(h) OFG (nearing clay-bound state)

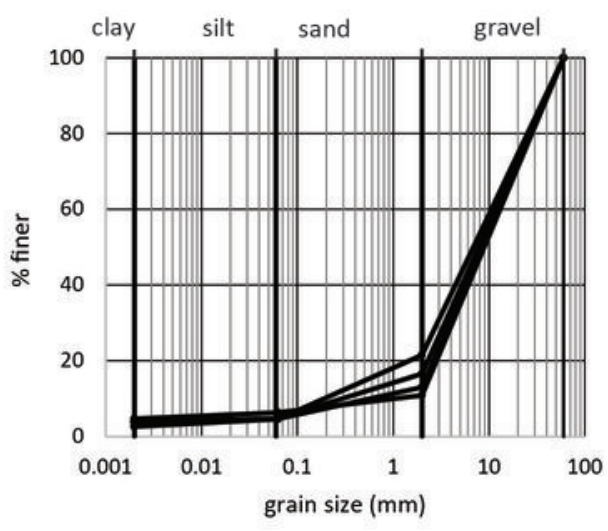




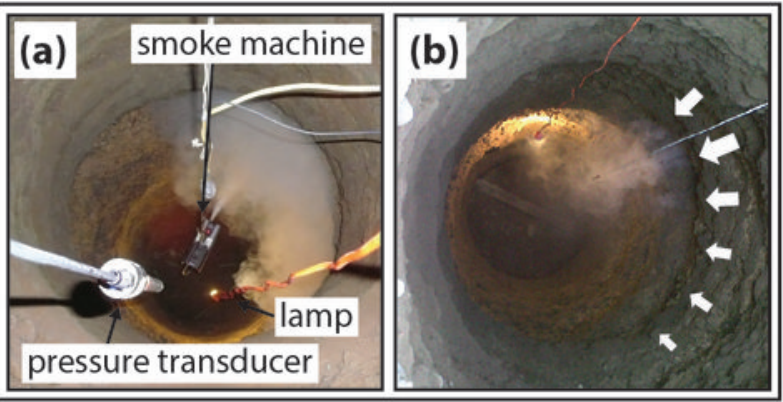


Horizontal (x-direction)

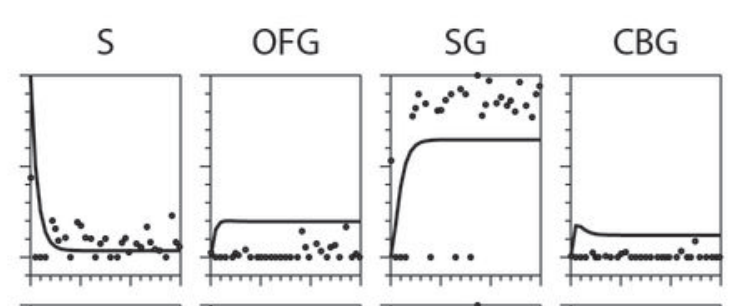

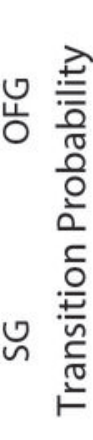
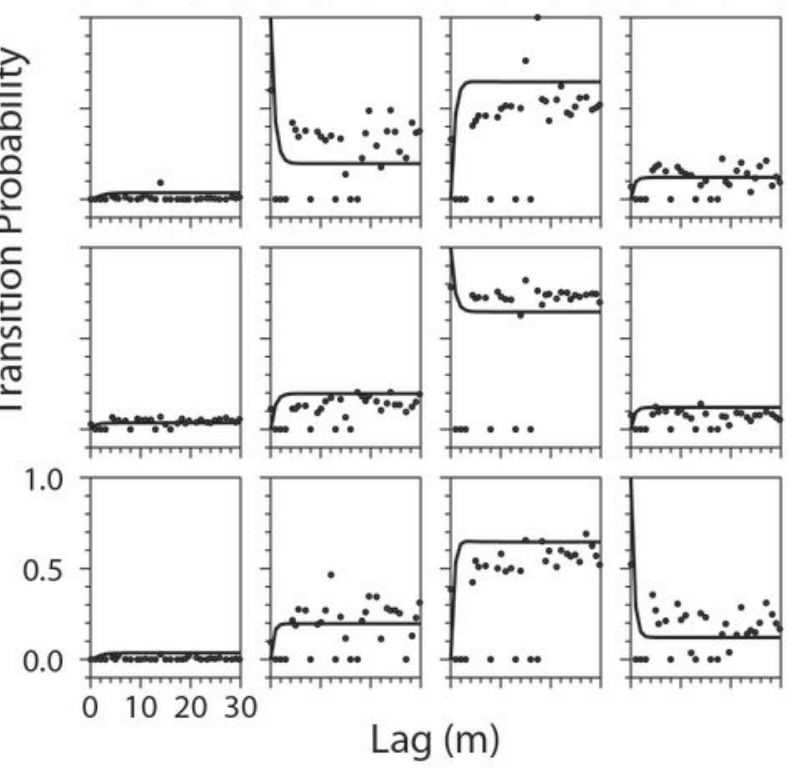

(b) Horizontal (y-direction)

(c)

Vertical (z-direction)
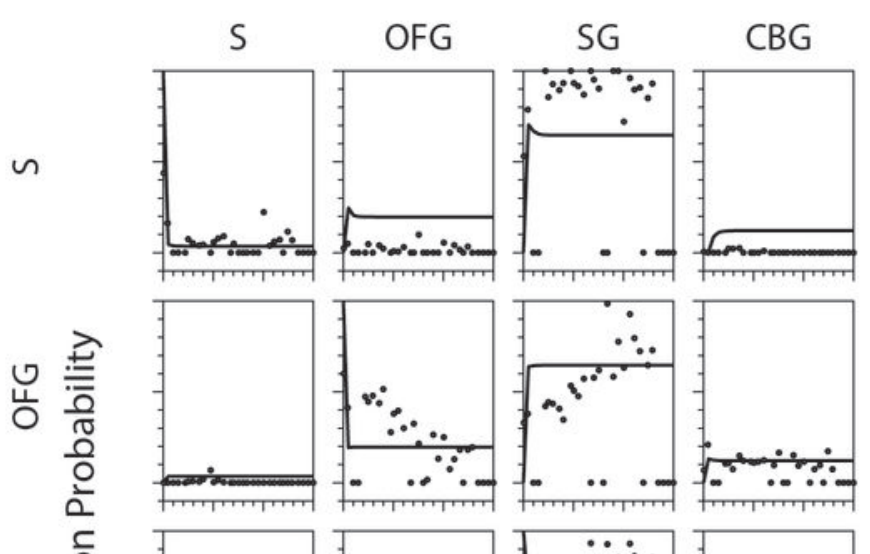

v
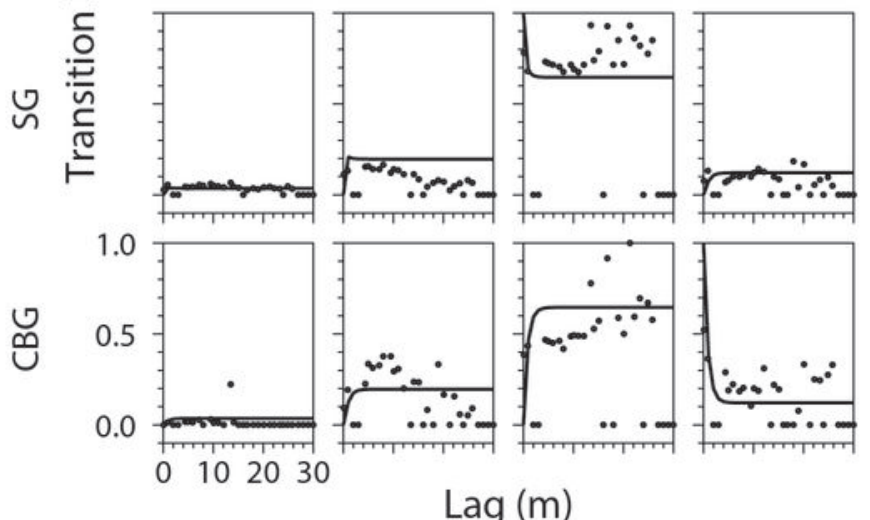
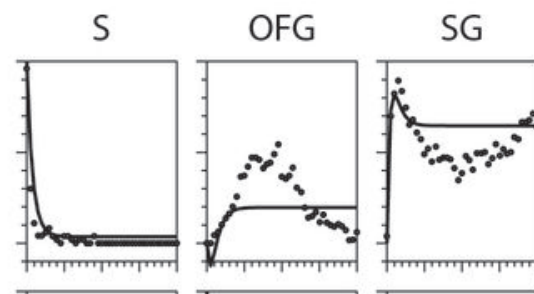

ن
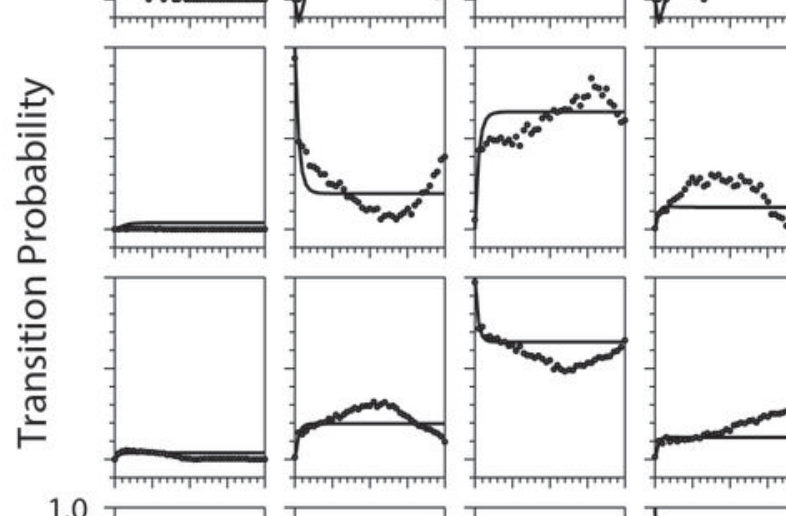

ن
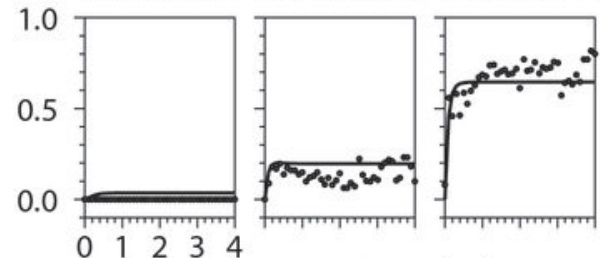

$\operatorname{Lag}(\mathrm{m})$

LEGEND: Measured Modelled 


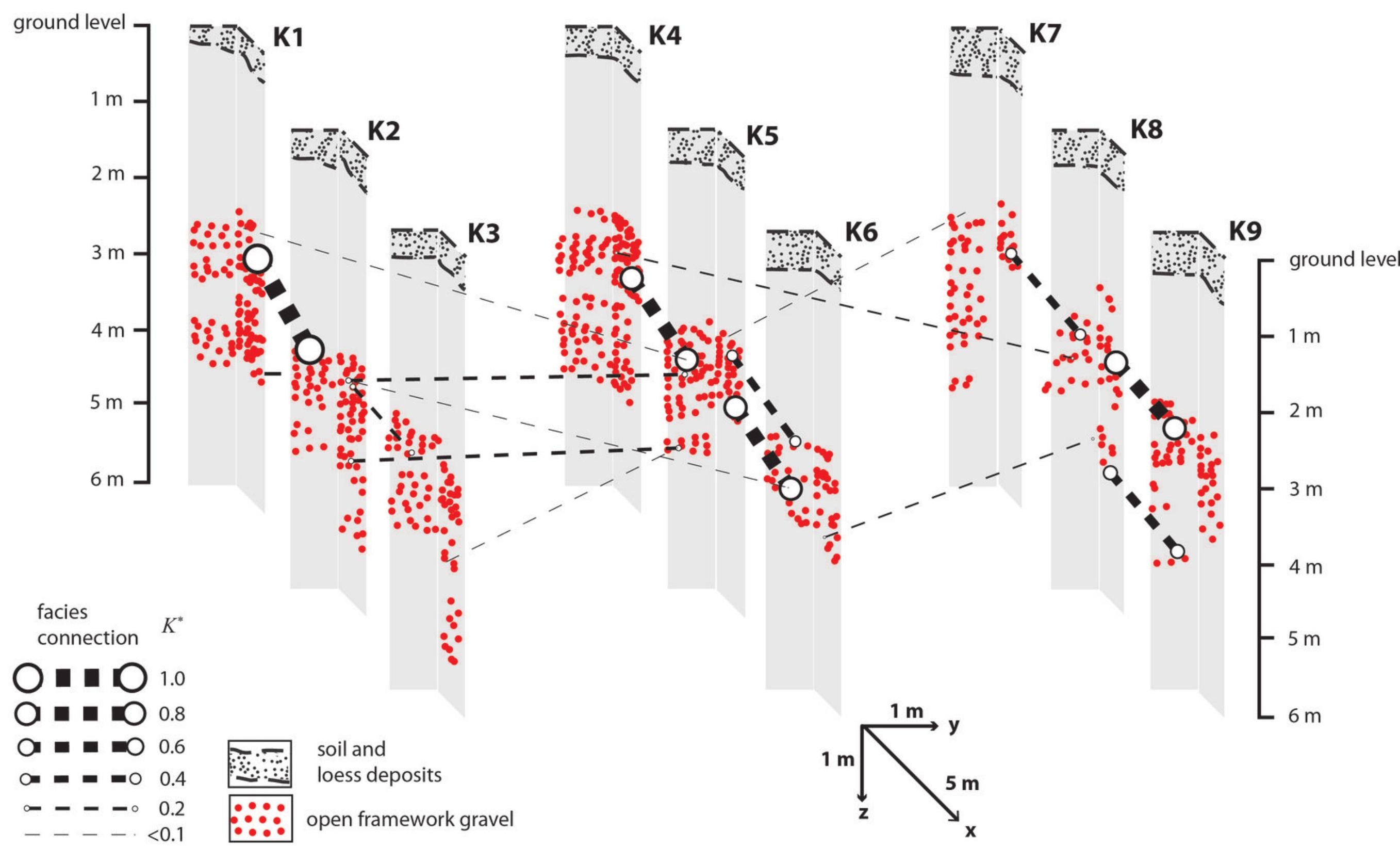




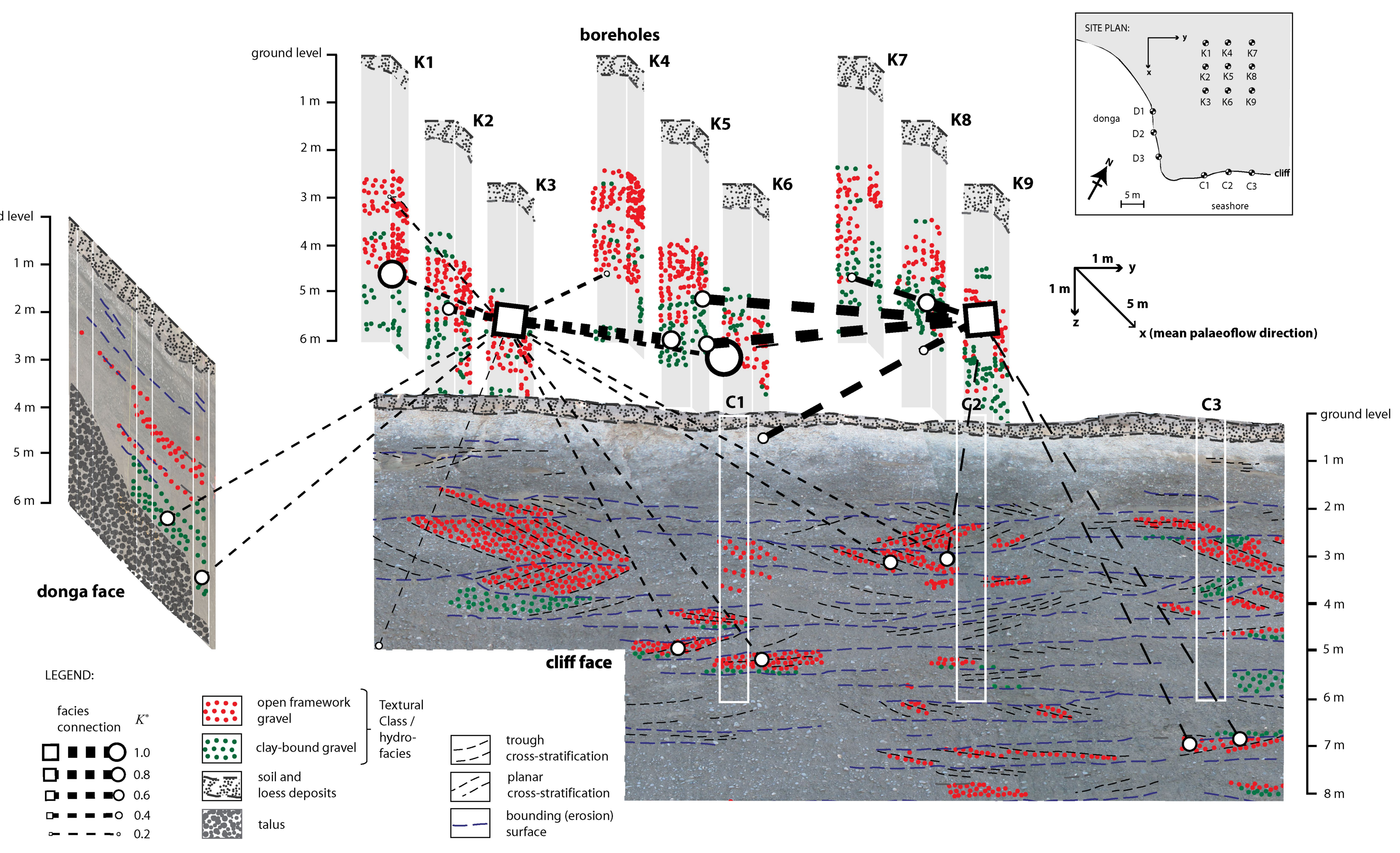

